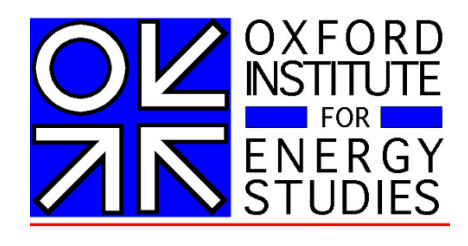

\title{
Political Economy of Electricity Reform
}

A Case Study in Gujarat, India

Christopher Joshi Hansen \& John Bower

Oxford Institute for Energy Studies

EL 03

September 2003 


\title{
Political Economy of Electricity Reform
}

\author{
A Case Study in Gujarat, India
}

Christopher Joshi Hansen \& John Bower

Oxford Institute for Energy Studies

57 Woodstock Road

Oxford OX2 6FA

Telephone: $+44(0) 1865311377$

Fax: +44 (0)1865310527

Email: chris.hansen@,oxfordenergy.org or john.bower@,oxfordenergy.org 
The contents of this paper are the authors' sole responsibility. They do not necessarily represent the views of the Oxford Institute for Energy Studies or any of its Members

\title{
Copyright $(9) 2003$
}

\section{Oxford Institute for Energy Studies}

(Registered Charity, No. 286084)

\begin{abstract}
All rights reserved. No part of this publication may be reproduced, stored in a retrieval system, or transmitted in any form or by any means, electronic, mechanical, photocopying, recording, or otherwise, without prior permission of the Oxford Institute for Energy Studies.

This publication is sold subject to the condition that it shall not, by way of trade or otherwise, be lent, resold, hired out, or otherwise circulated without the publisher's consent in any form or binding or cover other than that in which it is published and without similar condition including this condition being imposed on the subsequent purchaser.
\end{abstract}

ISBN 1901795241 


\section{CONTENTS}

Page

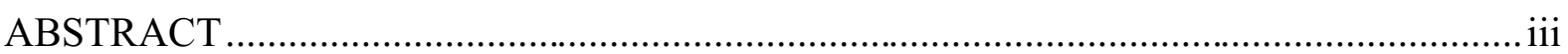

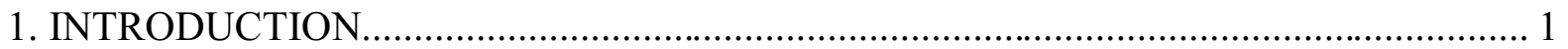

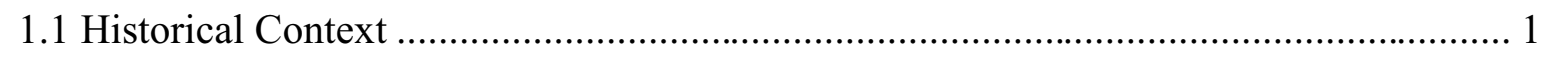

1.2 Constitutional Responsibility for Electricity ...................................................... 2

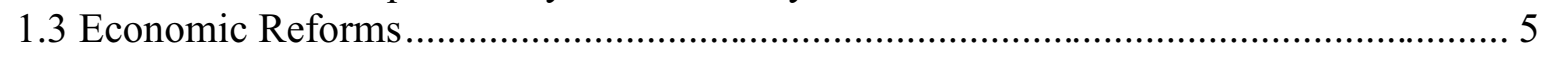

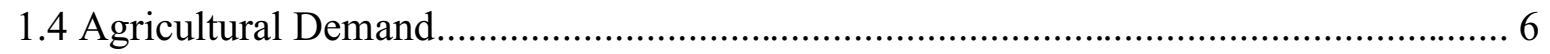

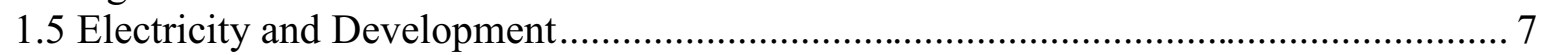

2. STRUCTURE OF THE GUJARAT ECONOMY AND ELECTRICITY SECTOR ......... 11

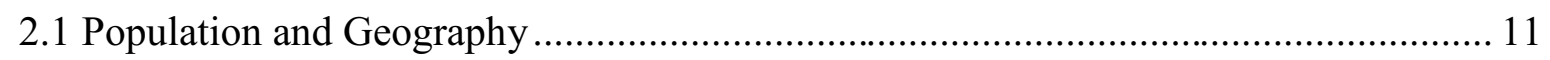

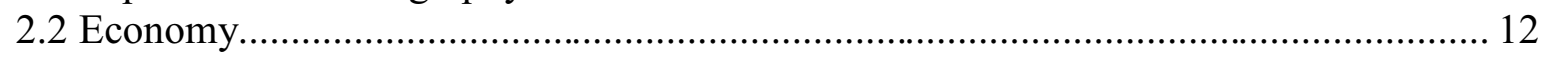

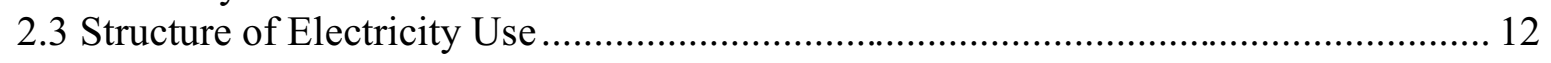

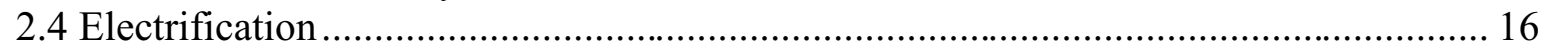

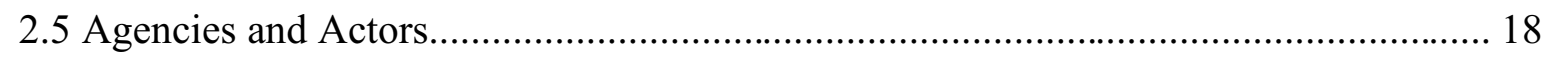

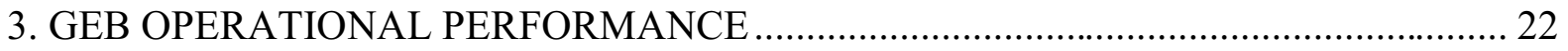

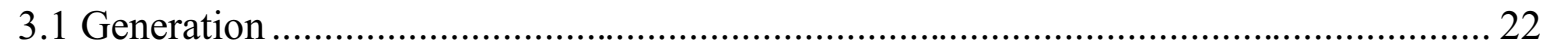

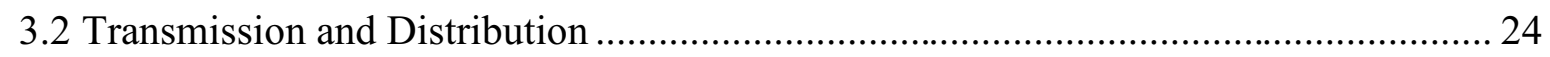

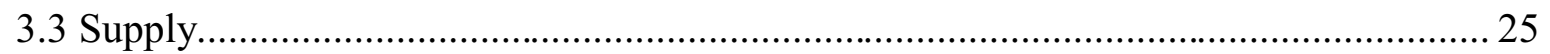

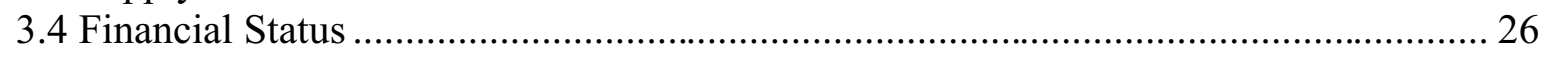

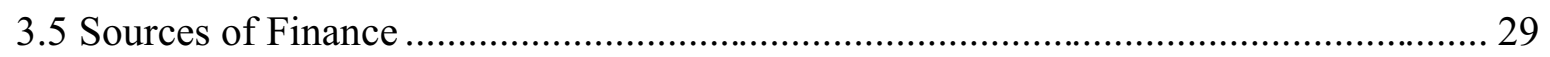

4. POLITICAL ECONOMY OF ELECTRICITY IN GUJARAT....................................... 31

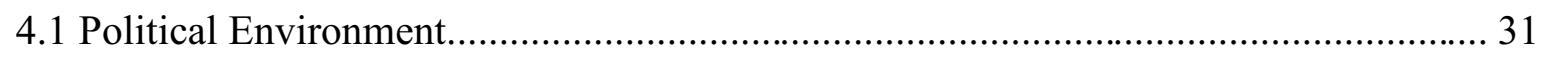

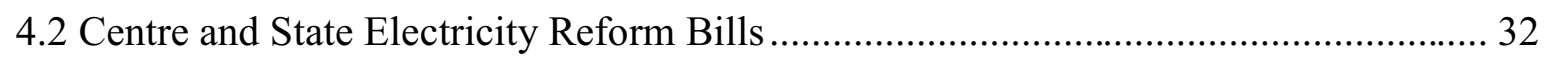

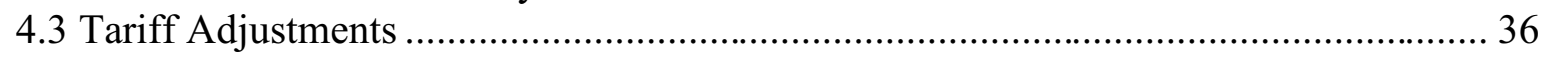

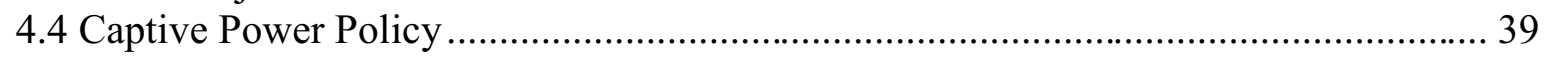

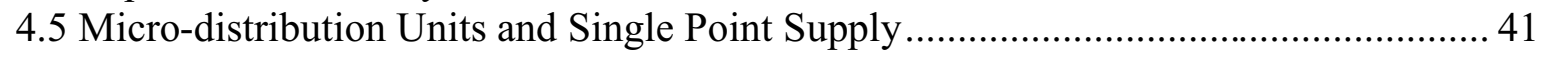

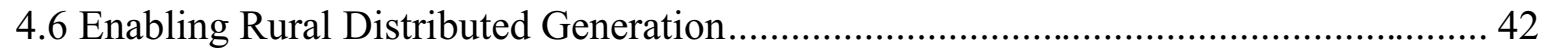

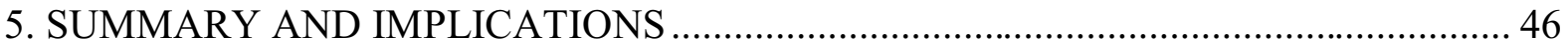

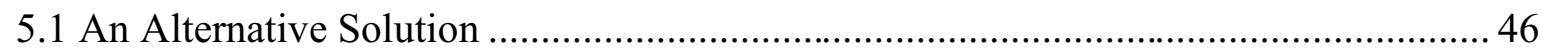

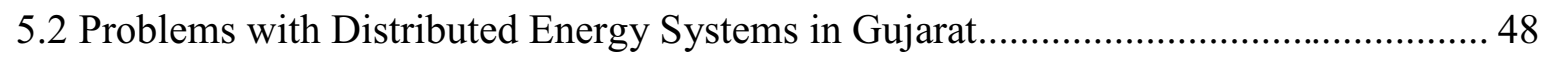

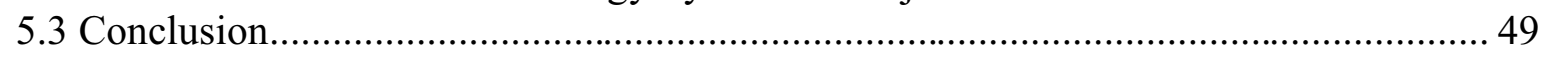

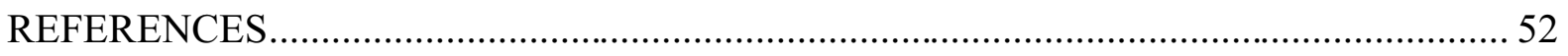




\section{FIGURES}

Figure 1.1: Sectoral Electricity Use in India (1960-2000) ............................................... 6

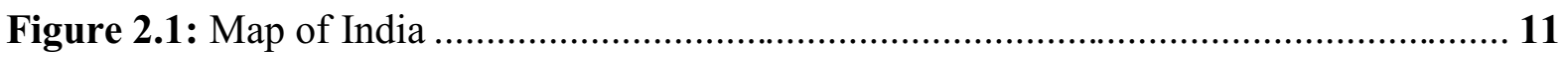

Figure 2.2: Sectoral Electricity Use in Gujarat 2001-2 .................................................... 13

Figure 3.1: Electricity Energy and Peak Demand Shortages in Gujarat, 1995-2002 ........... 22

Figure 3.2: GEB Profit and Loss Before Subsidy, 1992-2001 .......................................... 27

Figure 4.1: Forces in the Gujarat Power Sector Reform Process....................................... 33

\section{TABLES}

Table 1.1: Cost of Agriculture Subsidies in India ............................................................. 7

Table 2.1: Gujarat Real Gross State Domestic Product 1997-2001 (in 1993-94 prices) ...... 12

Table 2.2: Sectoral Electricity use in Gujarat 1995-2002, in million kWh .......................... 13

Table 2.3: Total Installed Generating Capacity in Gujarat State (1960-2002)..................... 14

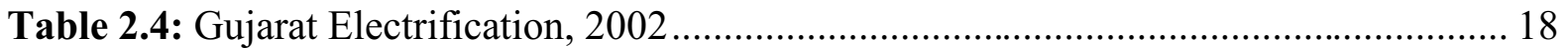

Table 2.5: Installed Capacity by Ownership in Gujarat September 2002, (MW)................. 19

Table 2.6: Share of Gujarat Generation by Supplier 2000-02, (MkWh) ............................. 19

Table 3.1: Gujarat Maximum Demand and Plant Load Factors 2001-2003......................... 23

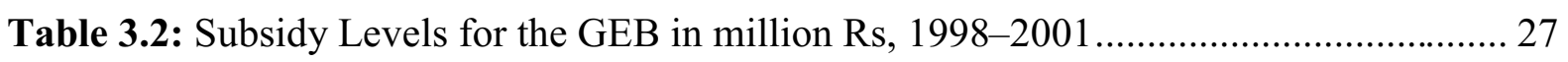

Table 3.3: Cost of Electricity for GEB and all-India Average, 1996-2001 (Rs/kWh) ......... 28

Table 4.1: Average Consumer Tariffs for Selected SEBs (Revised Estimate), 2000-2001 .. 37

Table 4.2: Consumer Category Percentage Increase in Tariff under GERC order 19-1999.. 38 


\begin{abstract}
In India, the supply of electricity relies heavily on a virtually bankrupt and sometimes corrupt system of state electricity boards (SEBs), which have failed to bring electricity to approximately $40 \%$ of rural households. High subsidy levels to agriculture and domestic customers and widespread electricity theft have resulted in weak financial conditions for the SEBs; and thus-top down remedies for improving the electricity system are not likely to be successful. The problems are particularly acute in Gujarat state, which represents a microcosm of the key issues faced throughout India, where a complicated and overlapping regulatory structure and new entrant prohibitions have stifled new electricity sector investment. This paper identifies and analyses the political and economic factors that have hindered progress. The main finding is that government may meet with greater success if it encourages and facilitates local private investment in small-scale electricity production, as a 'bottom-up' solution, rather than continuing attempts to force through 'top-down' reform of the existing state-owned electricity sector against entrenched interest groups.
\end{abstract}




\section{INTRODUCTION}

Beyond the technical and economic aspects of electricity service provision, it is the political processes that shape electricity supply industry (ESI) regulation that are most crucial to longterm success and efficient outcomes. The Indian electricity sector is now undergoing a process of changing regulatory structures and the first steps toward liberalising its electricity market. This paper uses a case study of the state of Gujarat as a microcosm of the current political economy landscape for the electricity sector in India and argues that government policy will need to adjust to a more flexible framework for electricity generation and distribution. Section 1 provides a historical background on state-led development in India, while section 2 highlights the structure of the electricity sector in Gujarat and describes the actors involved in the liberalisation process. Then the shortcomings of the state-owned utility in Gujarat, both in its operations and financial situation are described, followed by a discussion of the political contours in Gujarat as they relate to electricity sector reform especially in relation to the barriers for new entrants. In section 5, the key areas where progress has been made, and where progress is yet to be made despite the difficulties, are identified and an alternative route for Indian ESI liberalisation is sketched out, which takes into account the reality of the political and economic pressures that have been identified.

\subsection{Historical Context}

British colonial administrators began the decentralised development of an electricity infrastructure in India during the early twentieth century. Most electricity generation plants were built to support British industrial concerns and to supply electricity to the commercial and ruling-class families in the major cities (e.g. Bombay, New Delhi and Calcutta). Electricity was generated and distributed locally by private entrepreneurs, municipalities and provincial governments. For example, the hydroelectric project of the Tatas in Khandala supplied electricity to Bombay. There was little coordination or cooperation between the different suppliers in colonial India (Rao, 2002). The one major exception was the use of electricity for irrigation, which was first undertaken by the British in 1931 in present-day Uttar Pradesh and included 1500 tube-wells to irrigate 800,000 ha (Etienne, 2000). The 
success of this program led to a similar scheme in Punjab several years later. By independence in 1947 , a total of approximately $1400 \mathrm{MW}$ of capacity was installed.

\subsection{Constitutional Responsibility for Electricity}

The Indian constitution places the electricity sector in the "concurrent list," thereby granting responsibility for its management jointly to the central and state governments. The legal and regulatory basis for the management of the sector is derived from the Indian Electricity Act (1910); the Electricity Supply Act (1948); the Electricity Regulatory Commissions Act (1998); and now the Electricity Act (2003), passed in May 2003. The 1948 act allowed states to create generating companies and by the late 1950s all state governments had established state electricity boards (SEBs). The 1998 act established an independent regulatory commission at the federal level and allowed each state to set up state electricity regulatory commissions, known as SERCs. As of March 2003, 22 states had formed SERCs and 13 of them had passed tariff orders (MoF, 2003; ICRAb, 2003). The 2003 Act now requires each state to have a SERC. The SERCs are responsible for determining the tariffs to be charged to different classes of customers and the tariffs for and functioning of intrastate transmission. This duty is further encouraged and spelled out in the 2003 Act with open access and competition in the generation and distribution sector being the two primary goals of the legislation. However, despite this legal framework, the bifurcation of responsibility between state and central government has led to co-ordination failures in the Indian ESI, with many of the states slow to change the industry structure or reform tariffs. The passage of the new Electricity Act may signal the removal of the last political cover for the anti-reform forces within the states. The next part of this section describes the key agencies involved in the power sector at the national level.

The Ministry of Power (MoP) in India is concerned with planning, policy formulation, processing investment needs of public sector projects, monitoring the implementation of electricity projects, and manpower development. The MoP also administers and enacts legislation pertaining to generation, transmission, and distribution of thermal and hydroelectricity. The Central Electricity Authority (CEA) advises the ministry on technical, financial, and economic matters. The CEA is concerned with the development of uniform electricity policy in relation to the control and utilisation of national electricity resources. One 
of the main policy initiatives undertaken by the MoP has been the Accelerated Power Development \& Reform Program (APDRP), which is being used as a tool to assist SEBs in their reform efforts. Partners include the World Bank and the Asian Development Bank. One of the most important goals is to achieve $100 \%$ metering and better T\&D operations. The issue of reducing theft is also addressed with a broad effort to have each state pass more stringent anti-electricity theft legislation, a strategy that Gujarat is trying to implement (MoP, 2003).

The Ministry of Non-Conventional Energy Sources (MNES), created in 1992, was the first government ministry in the world dedicated to promoting renewable and alternative electricity sources. Working with state nodal agencies, such as the Gujarat Energy Development Agency (GEDA) which was founded in 1979, the MNES has promoted thousands of different electricity projects, including $1700 \mathrm{MW}$ of installed wind electricity in India and approximately $150 \mathrm{MW}$ in Gujarat (Patil, 2003). One offshoot of the MNES is the Indian Renewable Energy Development Agency Limited (IREDA), a public company established in 1987 to "develop and extend financial assistance for renewable energy and energy efficiency/conservation projects." To accomplish this goal, IREDA operates a revolving fund for the promotion, development and commercialisation of grid-scale electricity projects that utilize non-conventional sources of energy. The MNES, in conjunction with TERI, has recently established the SWHPTC (Small Wind and Hybrid Power Test Center) at Mithapur, Gujarat (Jongh and Rijs, 2000). The SWHPTC provides testing, product development, performance monitoring and training services for small wind systems, including wind-diesel hybrids.

The central government currently operates $30.4 \%$ of the generating capacity in India, approximately 30,000 MW, which is managed by three public companies - the National Thermal Power Corporation (NTPC), National Hydel Power Corporation (NHPC) and Nuclear Power Corporation (NPC); all three were established after amendments to the 1948 Electricity Supply Act (Rao, 2002). These three Public Sector Units (PSUs) can only sell electricity to the states, and the proportion of electricity allocated to each state has therefore been a point of contention, especially considering the acute electricity shortages faced by most SEBs. The NTPC was constituted in 1976 as a centrally-owned electricity generation company, responsible for building and operating large-scale thermal generating facilities and then selling the electricity to SEBs as per contractual agreement. Given that peak demand for 
electricity frequently outstrips available generation capacity on a state-by-state and all-India basis, the allotment of electricity from NTPC to the states has become a political process, although some states have not been able to take their full allocation because of the lack of adequate transmission capacity.

At the state level, the SEBs are responsible for ensuring generation, transmission, and distribution of electricity in India. The SEB installed generation capacity is $59.9 \%$ of the total nation-wide. Private electricity companies produce only $9.7 \%$ of total generation (Parikh and Parikh, 2002), which was allowed by legislative amendments in 1991 that permitted private investment, including foreign investment, in electricity generation plants (Rao, 2002). Given its chronic shortfall in electricity production and its inability to finance new investment in the sector the government of India began to allow private investment in new electricity generating capacity in 1991, in particular, industrial groups were allowed to build their own captive power plants to produce electricity for their own consumption.

Over the past decade, the Indian government has also aggressively pursued international Independent Power Producers (IPPs) in order to mobilise investor interest in investments in new generating capacity. In spite of various incentives offered by the government, private investment did not occur at the anticipated levels for a variety of reasons. The most critical inhibitor to IPPs throughout the 1990s was, and continues to be, a lack of security for investment recovery because most SEBs have a history of not paying for power in a timely manner. In addition, foreign firms have been discouraged by their past experiences of dealing with India's multi-level and ineffective bureaucracy, high taxes and unremunerative tariffs. They are naturally cautious to re-enter the market (USDoE, 2001).

The Indian government also continues to promote the building of large, so-called mega projects. These include large-scale thermal projects with capacity in excess of $1000 \mathrm{MW}$, or hydroelectric plants with capacities of at least $500 \mathrm{MW}$. Such projects qualify for exemption from customs and countervailing duties, and initial response to these incentives was strong; however, the slow pace of project development has disappointed foreign investors and most have backed out. In December 1999, Cogentrix Energy decided to cancel its participation in a project to build the $1000 \mathrm{MW} \mathrm{M}$ /Bangalore coal-fired plant due to bureaucratic delays and lawsuits by public interest groups. Daewoo Power of South Korea and ABB of Switzerland withdrew from a 1400 MW generation project in Madhya Pradesh in August 2000. For 
similar reasons, Electricité de France $(\mathrm{EdF})$ withdrew from construction of a plant in Maharashtra in July 2000 (USDoE, 2001). The mega-projects policy also angered smaller players in the electricity sector that were not eligible for the exemptions; however, the budget released on February 28, 2003 by the Ministry of Finance (MoF, 2003) has decreased the size (megawatt) requirement of projects eligible for 'mega-project' status and this should reduce the tax and custom duty costs for smaller projects.

\subsection{Economic Reforms}

With the stated goal of supporting development (IEA and OECD, 2002), the Indian electricity sector has grown rapidly in the past 20 years, expanding from 30,000 MW in 1981 to more than 100,000 MW installed capacity in 2001. However, this growth in capacity has not kept up with demand. Peak electricity shortages have remained above $18 \%$ and total electricity produced is $10 \%$ short of total demand. (Padmanaban and Sarkar, 2001). The Indian government is struggling to supply the industrial, residential, agricultural and commercial sectors with reliable electricity and has conceded that it can no longer fund large infrastructure investments in electricity, nor subsidise residential or agriculture customers at current levels. The electricity sector is virtually bankrupt as a result of protracted mismanagement and political interference. Haphazard and inadequate expansion of the transmission and distribution (T\&D) system has resulted in intermittent supply, low electricity quality ${ }^{1}$ and uneven distribution coverage, leaving many rural areas with poor electricity infrastructure.

More than $70 \%$ of the Indian population lives in rural areas, distributed over 580,000 villages (Neudoerffer, Malhotra, and Venkata Ramana, 2001), many of these areas are under-served by energy services, and thus rely on locally available biomass for most of their energy supply (ESMAP, 2002). The Indian government has made a concerted effort in the last 30 years to electrify the rural areas, especially for the purpose of energising irrigation pump sets. For example, SEBs have been aggressively electrifying rural areas of the country with the help of the REC, resulting in an official tally of $86 \%$ of the villages electrified, but most of the low income households away from the centre of the village do not have access to the grid

\footnotetext{
${ }^{1}$ Power quality refers to fluctuations in power voltage and frequency. Electricity must be supplied at a consistent voltage level in order not to cause damage to sensitive equipment such as computers and electric motors.
} 
(Gunaratne, 2002). However, despite the long-term government policy objective of rural electrification, and the prima facie success of 'electrifying villages', this belies the reality of a dearth of connections for many rural households and the poor quality of service available to those that have been connected.

\subsection{Agricultural Demand}

Electricity use in agriculture has increased rapidly in the past 30 years both because an average of 30,000 pump sets were electrified every year in India from 1970 to 2000, and because use per pump has climbed quickly. In Tamil Nadu for example, the electric use per pump has increased from $2501 \mathrm{kWh}$ in 1980-1 to $3897 \mathrm{kWh}$ in 1992-3 (Janakarajan, 2003). Though industrial and commercial electricity demand has climbed rapidly over the same period, the exponential growth in agricultural use means the overall share of industry and commercial users has declined relative to agriculture users, as shown in Figure 1.1.

Figure 1.1: Sectoral Electricity Use in India (1960-2000)

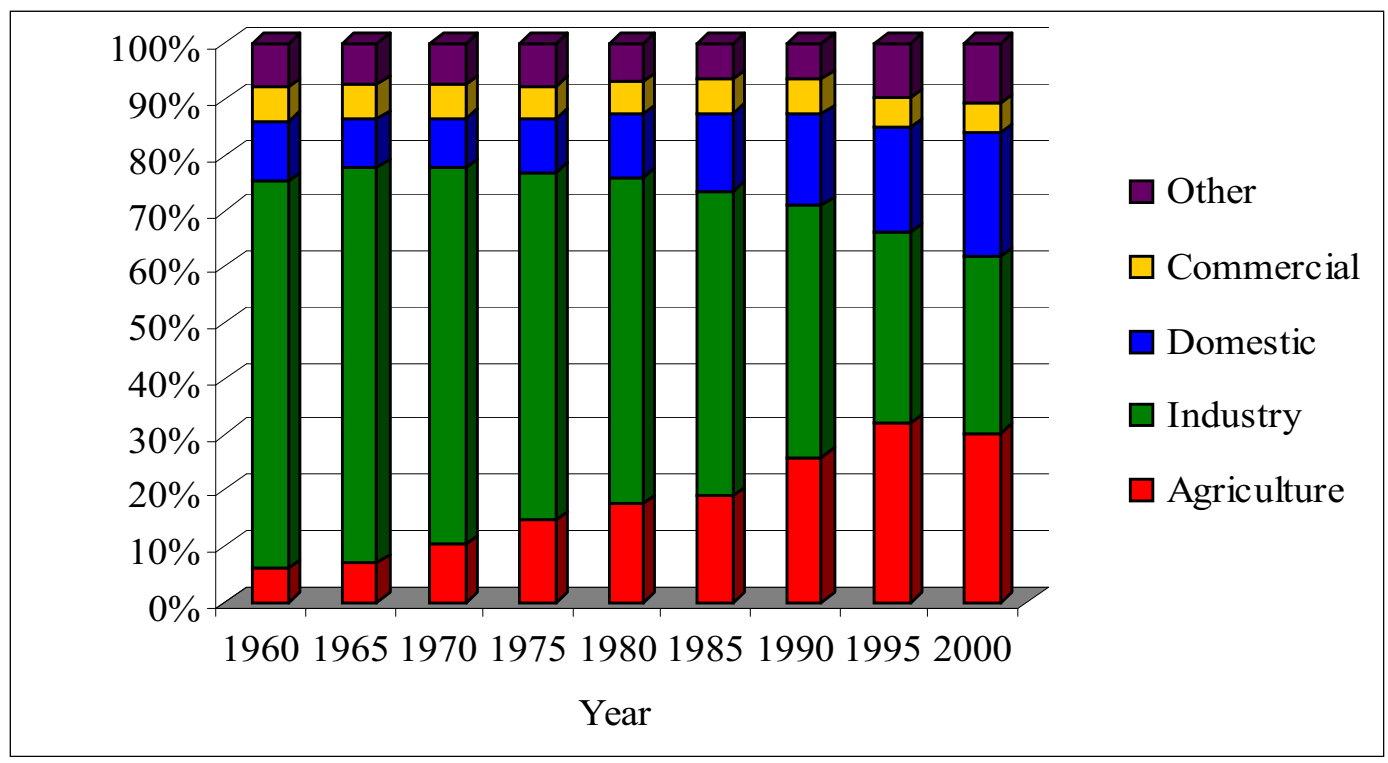

Source: (Rao, Kalirajan, and Shand, 1998; PC, 2002)

The domestic and agriculture sectors' electricity use has not only grown in gross units $(\mathrm{kWh})$ supplied, but is also becoming more expensive for the state to supply. Table 1.1 shows the disparity between the cost of supply and the average tariff in India for agriculture users, a gap that has been steadily growing, with the former increasing by 41\% from 1996-2001 while tariffs have increased by only $34 \%$. In total, the subsidy has risen by $74 \%$ in the same period 
because of the combined effects of higher use and lower relative tariffs. The cost of generation and distribution of electricity for agricultural use is also high, compared to other users, because the load is transported through long transmission and distribution lines that are needed to deliver the electricity to remote rural users.

Table 1.1: Cost of Agriculture Subsidies in India

\begin{tabular}{|l|l|rrrrr|c|}
\hline \multicolumn{1}{|c|}{ Category } & Unit & 1996-97 & 1997-98 & 1998-99 & 1999-00 & 2000-01 & Growth 1996-01 \\
\hline \hline Cost of Supply & Rs/kWh & 2.16 & 2.40 & 2.63 & 2.84 & 3.04 & $41 \%$ \\
Average Tariff & Rs/kWh & 1.66 & 1.80 & 1.81 & 1.99 & 2.12 & $28 \%$ \\
Average Ag tariff & Rs/kWh & 0.21 & 0.20 & 0.21 & 0.21 & 0.28 & $34 \%$ \\
\hline Subsidy for Ag Consumers & Rs billion & 155.9 & 177.1 & 206.9 & 246.0 & 270.8 & $\mathbf{7 4 \%}$ \\
\hline
\end{tabular}

Source: (Parikh, 2002)

\subsection{Electricity and Development}

Development has been the raison d'etrê of the modern Indian state and the source of its legitimacy. This section examines state-led development in India with regard to the electricity sector and how it has evolved from a socialist and developmentalist approach under Nehru to a more liberal reformist posture in the last 15 years. The constitution was written on the presumption that India would be a modern, and therefore secular, state endowed with the task of bringing about 'development' in what was thought to be a poor and backward society (Corbridge and Harriss, 2000). This led to massive state-directed investments in heavy industries, and included the building of electricity generation plants to support their growth.

In the 1970s there was increasing evidence of spreading food and income distress and new forms of poverty. This led to a shift in development thinking that stressed redistribution as a necessary strategy for economic development and was paid for in part by redirecting expenditures from industrialisation. New emphasis was placed on social development reducing urban poverty and meeting basic human needs by providing low cost housing, basic urban services, electricity connections, safe water supplies, and sanitation facilities (Beall, 1997). The late 1970s and 1980s saw another dramatic change in the ideas about development, with theorists questioning government's role and arguing for liberalisation, market deregulation, privatisation and a reduction in the size and scope of the public sector (Beall, 1997). As development faltered under the 'permit raj' and vestiges of central planning, the legitimacy of 
the government and thus the 'state' was called into question. However, dominant proprietary classes, most especially the rural elites and industrial leaders reinforced the government's role in development by demanding and receiving subsidies for electricity and fertiliser, and trade protection.

During the 1990s a package of liberalisation and reform measures was restarted in response to changing economic and political conditions. In 1991, the new Congress government came to power and accepted aid from the IMF to overcome a balance of payments crisis precipitated by the rise in oil prices in the run up to the first Gulf War in 1990. To stabilise the economy in the short term, the rupee was devalued and a stable line of credit was obtained from the IMF. This was followed by a recommencement of liberalisation efforts, which included: delicensing of industry, removal of export subsidies, shifting from import quotas to tariffs, reduction of tariff rates, financial liberalisation for investors, a substantial easing of the rules for foreign direct investment (FDI), and the process of state owned enterprise privatisation began which included the electricity sector (Ghosh, 2002).

Politically, these reforms have fared better than the program proposed under Rajiv Gandhi during the 1980s because as Jenkins (1999) argues in detail, the new reform package had staying power due to 'political incentives, political institutions and political skills.' The durability of liberalisation and reform has been tested by three changes of government during the 1990s, and even though the United Front and the BJP were on opposite ends of the political spectrum and both campaigned against liberalisation, they have nevertheless continued the reform programs. Jenkins credits the program's durability to the gradual nature of changes, which contrasts with Rajiv Gandhi's failed program of relatively rapid liberalisation during the years 1985-7. However the two efforts are not completely unrelated, and the first push probably laid the intellectual and political groundwork for the more successful staged reforms of the 1990s (Jenkins, 1999). The conclusion drawn by Jenkins is that democracies have a high capacity for reform and that the idea of the Indian state has successfully evolved. Going further, he argues that it is in fact because of the disorder of democracy that the real outcomes of liberalisation could be obfuscated and thus pass quietly.

Corbridge and Harriss (2000) argue somewhat more forcefully that 1990s liberalisation was a reinventing of the Indian state in response to the failed development oriented state where elites engaged with the masses in a paternalistic and modernising mode. As evidence, they 
cite the reform policies, inspired by neo-liberal economics and a political backlash against failed development policies, which helped increase the support for the RSS and VHP, and the closely tied Hindutva-based political party, the BJP - now in power in the centre and in many of the states, including Gujarat. This same backlash continued the ruralisation of Indian politics and left urban elites constrained by the increasing power of rich farmers and the growing rural and urban middle class (Corbridge and Harriss, 2000).

The pace of economic reforms has been gradual in India, as shown by the changes in the electricity sector. The slow pace has been blamed on the populist compulsions of democratic government and the deep-seated corruption in the Indian economy. However, Ahluwalia (1999) argues that the slow pace has made the process sustainable and has thus been supported by three successive governments: Congress (1991-95) United Front (1996-97) and the BJP (1998- ), which has recently declared its intention to continue structural reforms. Sustained measures over the past decade have led to some opening of the Indian economy and ultimately have more closely aligned it with the major economies of the world.

Despite the slow pace, the Indian experience of economic reform has therefore been one of mild success and provides support for gradual reform practices. Although Indian GDP growth has been between $4-5 \%$ for most of the 1990s, which is slower than the central government target of $8+\%$, the pace and sequence of reform has been politically sustainable and may bring more long-term benefits than if the reform had been deeper and implemented more quickly.

While the deteriorating financial situation is a strong argument in favour of India speeding up the reform process; because India does not possess regulatory institutions suited to handle quick change in either the financial or the newly privatised industry sectors, the question may be moot. Policy timing issues for the privatisation program highlights the fact that public divestment requires a solid commitment to market institutions and regulation. For example, the liberalisation of the electricity sector in India was started with the four-year-long creation of federal and state electricity regulatory commissions, which have had several years of dealing with the SEBs before moving ahead with any divestment plans. While this policy has allowed more time for companies to shed labour through attrition and adapt their internal operating procedures in anticipation of the change, it has come at a high cost to the public coffers because of continued subsidies needed to prop up the poor performance of the state- 
owned utilities. For example, more than $1 \%$ of GDP is being used to subsidise the electricity industry in India (Ahluwalia, 1999). The more progressive approach in the Electricity Act 2003 signals a more radical market opening by allowing all groups of consumers to exit SEB service and generate their own power. However, the expensive and politically-sensitive subsidy issue is left to each state to decide. 


\section{STRUCTURE OF THE GUJARAT ECONOMY AND ELECTRICITY SECTOR}

To put the myriad of Indian electricity reform issues into context, the remainder of this paper examines the political and regulatory forces in the western state of Gujarat, whose electricity sector is a good microcosm of the issues facing ESI reform in many of the states in India.

\subsection{Population and Geography}

The western state of Gujarat, population 51 million in 2001, is located on the southern section of the Pakistan border and has a long coastline with the Arabian Sea, as shown in Figure 2.1. The state has both rich farmland in the centre and south and dry areas in the west. Surface water is scarce, though the new Narmada Dam project promises to allow increased agricultural irrigation to regions without accessible and useable groundwater.

Figure 2.1: Map of India

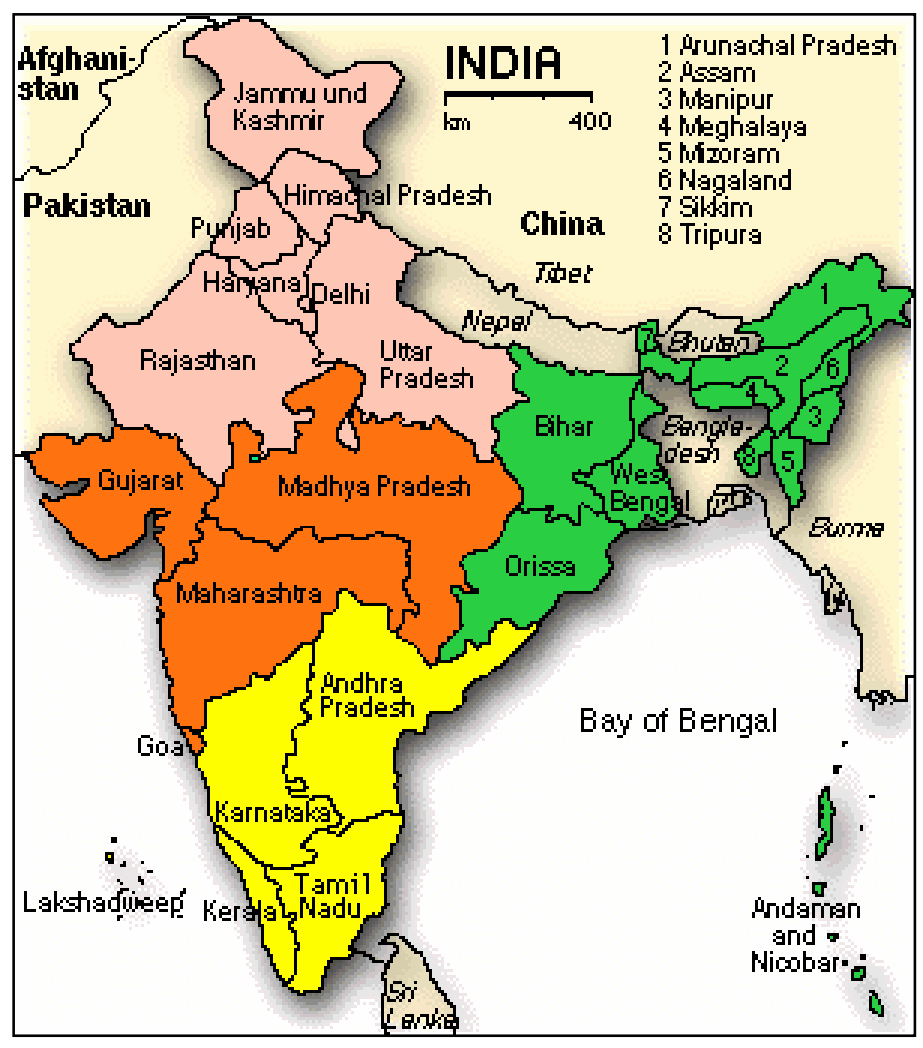

Source: (http://www.indiatouristoffice.org) 


\subsection{Economy}

The Gujarat economy has had sporadic economic growth since 1997, as shown in Table 2.1, with growth being particularly sluggish over the last two years. High population growth rates, above 2\% per annum, have diluted the Gross State Domestic Product (GSDP) gains, with Gujarat adding more than 9 million people from 1991 to 2001 to its present total of 50.6 million. The state has a relatively well-developed infrastructure base and is home to many large electricity consuming industries, including 30\% of India's chemical and textile industries and $12 \%$ of its sugar industry (PLR, 1998). In addition, it has a large agriculture sector that in many locations is reliant on electrically powered pumping of underground water to maintain production.

Table 2.1: Gujarat Real Gross State Domestic Product 1997-2001 (in 1993-94 prices)

\begin{tabular}{|l|r|rrrr|}
\hline & \multicolumn{1}{|c|}{ Unit } & 1997-8 & 1998-9 & 1999-00* & 2000-1* \\
\hline \hline $\begin{array}{l}\text { Total Gross State } \\
\text { Domestic Product }\end{array}$ & Billion Rs & 714.4 & 765.7 & 756.2 & 761.0 \\
\hline $\begin{array}{l}\text { Percentage change over } \\
\text { previous year in GSDP }\end{array}$ & $\%$ & 2.1 & 7.2 & -1.2 & 0.6 \\
\hline $\begin{array}{l}\text { Per Capita Gross State } \\
\text { Domestic Product }\end{array}$ & $\mathrm{Rs}$ & 15335 & 16200 & 15768 & 15634 \\
\hline $\begin{array}{l}\text { \% change on previous year } \\
\text { GSDP/capita }\end{array}$ & $\%$ & 0.7 & 5.6 & -2.7 & -0.9 \\
\hline
\end{tabular}

*estimates

Note: Chart in constant prices, using 1993-4 Rs as base year.

Source: (GoGa, 2003)

\subsection{Structure of Electricity Use}

Electricity use by different sectors of the Gujarat economy is summarised in Figure 2.2 and Table 2.2. If accepted at face value, these data indicate an increasing agricultural component and a shrinking industrial use. However, while it is true that industry is becoming more energy efficient, spurred on in part by the high tariffs in the sector, agricultural use is exceedingly high and has been questioned by virtually every consumer and industrial group that appeared before the GERC during the tariff order consultations (GERC, 2000). 
It is also worth noting that per capita consumption has increased steadily to $963 \mathrm{kWh} /$ capita in Gujarat and is well above the all-India average of approximately $400 \mathrm{kWh} /$ capita. Gujarat has been successful at increasing generation capacity in the last five years by adding 2000 MW since early 1997; however, a significant shortfall still exists and more capacity, better efficiency, or a combination of the two is badly needed as shown in Table 2.4.

Figure 2.2: Sectoral Electricity Use in Gujarat 2001-2

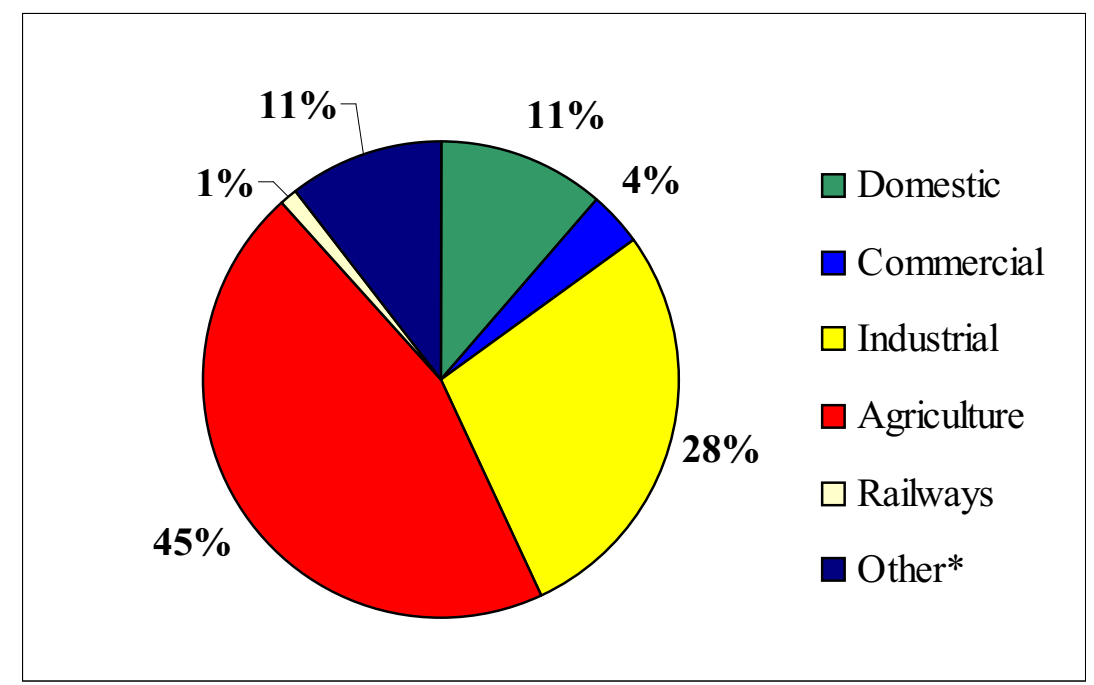

Source: (GoGa, 2003)

Table 2.2: Sectoral Electricity use in Gujarat 1995-2002, in million kWh

\begin{tabular}{|c|c|c|c|c|c|c|c|c|}
\hline Year & $\begin{array}{c}\text { Domestic } \\
(\mathrm{MkWh})\end{array}$ & $\begin{array}{c}\text { Commercial } \\
(\mathrm{MkWh})\end{array}$ & $\begin{array}{c}\text { Industrial } \\
(\mathrm{MkWh})\end{array}$ & $\begin{array}{c}\text { Agriculture } \\
(\mathrm{MkWh})\end{array}$ & $\begin{array}{c}\text { Railways } \\
(\mathrm{MkWh})\end{array}$ & $\begin{array}{l}\text { Other* } \\
(\mathrm{MkWh})\end{array}$ & $\begin{array}{c}\text { Total } \\
(\mathrm{MkWh}) \\
\end{array}$ & $\begin{array}{c}\text { kWh per } \\
\text { capita }\end{array}$ \\
\hline $1995-96$ & 2838 & 890 & 10376 & 10151 & 331 & 2552 & 27138 & 693 \\
\hline 1996-97 & 2968 & 931 & 11048 & 10105 & 345 & 2685 & 28082 & 724 \\
\hline $1997-98$ & 3171 & 1003 & 11065 & 10774 & 349 & 2988 & 29350 & 786 \\
\hline 1998-99 & 3486 & 1097 & 10940 & 12061 & 358 & 3126 & 31068 & 848 \\
\hline 1999-00 & 3699 & 1178 & 10284 & 14934 & 379 & 3355 & 33829 & 932 \\
\hline 2000-01 & 3981 & 1279 & 9813 & 15489 & 383 & 3380 & 34325 & 953 \\
\hline 2001-02 & 3922 & 1278 & 9817 & 15695 & 406 & 3679 & 34797 & 963 \\
\hline \begin{tabular}{|l|}
$\%$ Increase \\
from 1995-02
\end{tabular} & $38.2 \%$ & $43.6 \%$ & $-5.4 \%$ & $54.6 \%$ & $22.7 \%$ & $44.2 \%$ & $28.2 \%$ & $39.0 \%$ \\
\hline
\end{tabular}

* include public lighting and public water system consumption

Source: (GoGa, 2003) 
Table 2.3: Total Installed Generating Capacity in Gujarat State (1960-2002)

\begin{tabular}{|r|r|r|}
\hline \multicolumn{1}{|c|}{ Year } & MW & \% growth/yr \\
\hline \hline 1960 & 315 & \\
1965 & 527 & \\
1970 & 830 & \\
1975 & 1283 & \\
1980 & 2385 & \\
1985 & 3384 & \\
1990 & 4823 & \\
\hline 1995 & 6363 & \\
1996 & 6630 & \\
1997 & 7582 & \\
1998 & 8093 & $14.4 \%$ \\
1999 & 8343 & $6.7 \%$ \\
2000 & 8582 & $3.1 \%$ \\
2001 & 8651 & $2.9 \%$ \\
\hline 2002 & 8890 & $0.8 \%$ \\
\hline Note- includes state, central and private capacity
\end{tabular}

Source: (GoGa, 2003)

As a result, consumer and industry groups in Gujarat are increasingly concerned about the high growth rate of electricity demand from agriculture, 54.6\% since 1995, which has drained the state budget and siphoned physical electricity supply away from other sectors of the economy. This has had the dual effect of increasing (upward) pressure on industrial tariffs, the ultimate payer of any cross-subsidisation, while quality and reliability of electricity supply have decreased for all consumers.

In Gujarat state alone, the subsidy totalled Rs 14.56 billion in 1996, while the total for the nation amounted to Rs 270.83 billion in $2001^{2}$. This represents $1.5 \%$ of GDP and a diversion of resources from other critical areas, such as education and health care. The cause of this subsidy entrenchment is that short-term electoral advantage has repeatedly been placed ahead of dealing with the serious medium- and long-term consequences of allowing the largest and fastest growing electricity end-use sector (farmers) to have free or subsidised electricity. By 2000-01, GEB claimed that the agricultural sector constituted approximately $45 \%$ of the total electrical energy units consumed in Gujarat. At present, over $95 \%$ of the sale of energy units that are reported under this consumer category are unmetered. By over-reporting sales to the subsidised agriculture users, individual managers of the GEB can sell the electricity to

\footnotetext{
${ }^{2}$ In 2000-01, agriculture and domestic cross-subsidies for all of India totaled Rs 345.87 billion, up from Rs 74 billion in 1991-92 (MoF, 2003)
} 
industrial users or rich domestic consumers and create a rent equal to the quantity sold multiplied by the price difference. The assessed sale of energy units reported under the agricultural segment has been questioned by the GERC (ICRA, 2003) as well as Sebastian Morris $(2002, \mathrm{c})$ who asserts that much of the electricity that is claimed to be used by the agriculture sector is in fact diverted to illegitimate uses, a claim strongly denied by the GEB. The GEB board member for Finance goes as far as to call Professor Morris a "worthless individual," who is "completely out of touch with reality" (Srivastava, 2003).

Sebastian Morris (2000) argues that the figures from the GEB and now GERC are flawed because they are grossly out of line with neighbouring states on a per pump set basis. For example, per pump set consumption in Gujarat would be 2-3 times higher than that of Maharashtra, Karnataka, Tamil Nadu, and Andrha Pradesh. In other words, each Gujarat pump set would be running the equivalent of $1 / 3$ of the year, a practical impossibility both because of water limitations and because the electricity supply to rural areas is cut off with such regularity. The other argument that undercuts GEB's claim of high agriculture use, and thus high subsidy payments from the government, is the large mismatch between the GEB claim of total losses (20\%) and GERC's final determination during the first tariff order issued in October of 2000, of losses of 34\% (GERC, 2000). The problem is given full treatment in the tariff order:

GEB has shown the agricultural consumption as 13,600 MU as per its revised estimate submitted on July 1, 2000. The Commission has computed such consumption on the basis of the installed capacity of the pumps and the norms prescribed by Mishra Committee and that comes to nearly $9,165 \mathrm{MU}$. It is therefore clear that substantial quantity of consumption is shown by way of agricultural use and as such it is difficult to assess use of unauthorized power or loss of power by way of theft that might have been added or included in the use of agricultural sector. These all have resulted on account of unmetering supply to the agricultural sector (GERC, 2000):102).

However, GERC recently commissioned a scientific study from $\mathrm{TERI}^{3}$ that appears to support the GEB's position by demonstrating that agriculture consumption is above $40 \%$ of the total. This study was done by sampling several districts. TERI selected 44 sample feeders

\footnotetext{
${ }^{3}$ The study by TERI was completed in 2003 and is not publicly available. The author was able to look at the findings, but was not able to obtain a copy of the results. The methods employed were well tested sampling techniques, but may have missed the most grievous outliers of 'agriculture' use and therefore under represented the total amount of power that is stolen or 'misdirected'.
} 
across all categories, $1 \%$ of total feeders, and conducted studies in each zone of the GEB. Results of each zone's sample feeders were then extrapolated to find the total agriculture consumption and electricity losses. Results from rural feeders with mixed loads were crosschecked with results of rural feeders having only agricultural connections. Total losses found were in the order of $28.8 \%$ and total agriculture consumption was $13,345 \mathrm{kWh}$, which was $42 \%$ of total consumption. This study "proves that agriculture consumption is in order of $40+\%$ " (Shah a, 2003). While the author does not doubt the validity of this GERC sponsored study, the GEB itself admits to poor record keeping (GERC, 2000) and has mounted little in the way of direct evidence against the claim, and the metering problem, as expounded in the tariff order remains a huge problem:

\footnotetext{
The electrical supply was measured till 1983 in agricultural sector, when the HP based tariff was introduced. However, the meters have been removed, thereafter, supplying electricity in agricultural area is on HP basis. Therefore, on account of removal of the meters, the quantum of the energy supplied in agricultural sector is not known nor it can be known reasonably (GERC, 2000):101).
}

Agriculture uses large quantities of locally available non-commercial energies, such as manure and animate (e.g. draft animals) energy. In addition, higher value, commercial energy sources are used directly and indirectly in the form of diesel, electricity, fertiliser, plant protection, chemicals, irrigation water, machinery, etc. (Singh, Mishra, and Nahar, 2002). To meet electricity demands, rural electrification programs were begun in the $1950 \mathrm{~s}$ as a social amenity, but by the late 1960 s the efforts were co-opted by agriculture planners as a way to increase farm production through electrified pump sets for irrigation. It was hoped that ready access to electric power would not only benefit irrigators, but also enhance rural income generation by increasing small manufacturing and enabling educational opportunities. The Rural Electrification Corporation (REC) was formed in 1969 with a charge to electrify all villages in India; it claimed to have electrified 84\% of villages by 1993 .

\subsection{Electrification}

The Government of Gujarat (2003, a) claims that the state is 'fully electrified', with the exception of 88 'non-feasible' villages - that will be supplied through off-grid, distributed generation (DG) projects (MoP, 2002). The total number of rural households in Gujarat as per 
the government census of $1991^{4}$ is $4,792,660$ and the Ministry of Power (2002) claims that $56.4 \%$ of those households have an active electrical connection. The GEB makes a similar claim, that $52 \%$ of all households in the state are electrified through legal connections, but Gujarat household surveys by the National Council of Applied Economic Research (2002) indicate that actual electrical connection rates are much higher, especially for the rich. Table 2.4 highlights the differences for all households in Gujarat in 2002 and implies that at least $20 \%$ of all connections are illegal.

Unfortunately, the promise of electricity for all has been over-sold and under-delivered. The government claims to have electrified 212,634 villages between 1980 and 1991 (Ravindranath and Hall, 1995), but this number includes many cases where transmission lines pass through the village but without providing actual connections to individual households. A village was considered to be electrified if electricity was "used within its revenue area for any purpose whatsoever." This definition was changed in 1997 to read: "a village is deemed to be electrified if electricity is used in the inhabited locality within the revenue boundary of the village for any purpose whatsoever" (Pandu, 2003):38). In Bihar and Uttar Pradesh the 'liberal' definition problem is most pronounced; only 4.4 and 9.3 percent of rural households have electricity service, and the vast majority of these are wealthy, large landholding farmers. Overall, only $27 \%$ of rural households use electricity for lighting, a significant disparity from the $100 \%$ claim of electrification in many states such as Gujarat.

Rural electrification programs have fallen short for a number of reasons:

i. Transmission lines are expensive to build and without a large (paying) consumer base in the rural areas, these high capital costs cannot be recovered;

ii. Long distances covered by distribution lines result in high electricity losses, estimated at 2.4 times the rate in urban areas (Ravindranath and Hall, 1995);

iii. Political patronage is used to fill the majority of jobs in the state-owned electricity sector, which has resulted in inefficiencies not only in terms of superfluous staff costs but also in building and maintaining the transmission and distribution (T\&D) network to rural areas;

iv. Even where working infrastructure exists, the goal has generally been to provide cheap electricity for irrigation, not to electrify new domestic consumers;

\footnotetext{
${ }^{4}$ Complete 2001 census results in Gujarat are not available due to the disruption caused by the earthquake in 2001
} 
v. Low tariffs in the agriculture and domestic sector leave few resources for Indian utilities to expand or even maintain levels of service;

vi. Local councils do not have adequate access to finance to bypass the central government's rural electrification programs and provide energy services directly to households, thus there is no competition and no market pull mechanism; and

vii. The current level of demand by the rural poor is too small and the co-ordination failures and investment risks too high for the private sector to be motivated to adequately respond.

Table 2.4: Gujarat Electrification, 2002

\begin{tabular}{|lc|}
\hline Household Income (Rs/yr) & \% \\
\hline \hline under 20,000 & 60.4 \\
$20,001-40,000$ & 83.6 \\
$40,001-62,000$ & 89.3 \\
$62,001-86,000$ & 93.3 \\
Above 86,000 & 93.4 \\
\hline All Income Levels & $\mathbf{7 1 . 9}$ \\
\hline
\end{tabular}

Source: (NCAER, 2002)

An important variable that the above figures do not adequately capture is the quality of service in terms of the quantity of electricity that is actually delivered and the regularity of the supply. These are both major shortcomings of the present system. The lack of any connection and lack of good quality legal connections in rural areas are both strong reasons for innovative, non-centralised solutions to be examined as alternatives to centralised grid electricity in non-urban areas of India.

\subsection{Agencies and Actors}

Since 1991, the structure of the Indian electricity sector has become more complex, with new private units and increasing amounts of captive power being added to the mix. Rao (2002) sums up the situation succinctly:

...there are SEBs generating and distributing power in the states, CPSUs generating and transmitting power to be sold on a pre-agreed basis to different states with tariffs set by the central government, private generating companies, private transmission companies, private 
distribution companies (in addition to licensees), central and state transmission utilities, regional and state load dispatch centers, central and state electricity regulatory commissions, and the Central Electricity Authority (CEA). However, the SEB has a veto over any new generation in its state and supply by any non-SEB generator to customers within its state. Trading as an activity in electricity is not recognized and access to transmission lines is at the discretion of the central/state transmission utility (Rao, 2002):5).

The GEB caters for 7.13 million consumers spread across the state through 705 sub-stations and a lengthy T\&D network. The following section describes the key actors in the Gujarat electricity sector with the principal relationships between them summarised in Figure 2.3. The GEB has recently divested itself into two semi-autonomous private companies, Gujarat Electric Transmission Company Limited (GETCL) and Gujarat State Electricity Corporation Limited (GSECL). GETCL was incorporated on May 19, 1999, but the transfer of up to $66 \mathrm{KV}$ of transmission lines from GEB to GETCL is yet to be effected. GSECL is the generating company promoted by the GEB and owns an installed generating capacity of 420 MW. The other important aspect of Gujarat electricity generation is the changing nature of ownership as shown in Table 2.5 and Table 2.6.

Table 2.5: Installed Capacity by Ownership in Gujarat September 2002, (MW)

\begin{tabular}{|r|rrr|r|}
\hline \multicolumn{1}{|c|}{ Year } & \multicolumn{1}{c}{$\begin{array}{c}\text { GEB } \\
\text { Total }\end{array}$} & $\begin{array}{c}\text { Private } \\
\text { Sector }\end{array}$ & $\begin{array}{c}\text { Central } \\
\text { Sector }\end{array}$ & $\begin{array}{c}\text { Total } \\
\text { Generation }\end{array}$ \\
\hline \hline 2000 & 23177 & 14829 & 11373 & 49379 \\
2001 & 23327 & 13645 & 13534 & 50506 \\
2002 & 22920 & 12084 & 15065 & 50069 \\
\hline$\%$ in 2002 & $45.8 \%$ & $24.1 \%$ & $30.1 \%$ & \\
\hline
\end{tabular}

Source: (GoGa, 2003)

Table 2.6: Share of Gujarat Generation by Supplier 2000-02, (MkWh)

\begin{tabular}{|l|r|r|}
\hline State $($ GEB $)$ & 4712.7 & $53.0 \%$ \\
Central & 1538.3 & $17.3 \%$ \\
Private & 2639.8 & $29.7 \%$ \\
\hline Total & 8890.8 & \\
\hline
\end{tabular}

Source: (GoGa, 2003) 
Figure 2.3: Schematic of Gujarat Power Sector, 2003

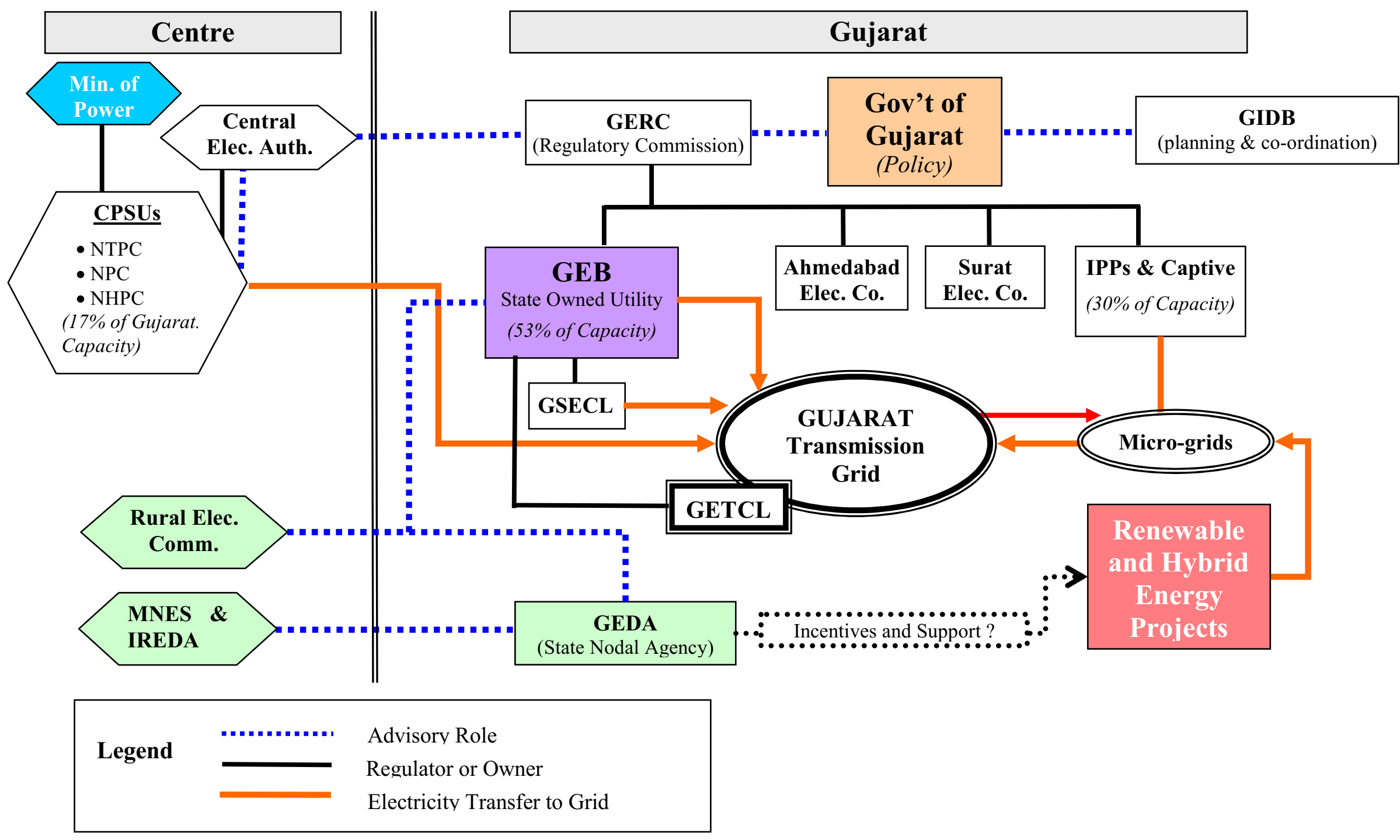


GERC was constituted under the ERC Act of 1998, commenced its operations from April 1, 1999, and is functioning as the sole regulatory authority in the State. In its four years of operation, the GERC has issued tariff orders for the GEB, Ahmedabad Electricity Company (AEC), and the Surat Electricity Company (SEC). The commission has attempted to reduce the level of cross-subsidy by ordering a pronounced hike in tariffs for the residential, public lighting and the agricultural segments, while at the same time ordering a small increase for the industrial sector (ICRA, 2003). The policy function of the GERC is limited to tariff and operational orders for licensees, most notably, the GEB. However, the new Electricity Act in both the Gujarat and National Parliaments has opened up new authority for the GERC, especially in setting the direction and pace of new captive generator capacity additions. Long-term planning and fuel policy is still the responsibility of the state power ministry, currently in the Chief Minister's portfolio (Sharma, 2003).

In 1995, the GoG established the Gujarat Infrastructure Development Board (GIDB) to "facilitate higher flow of funds into infrastructure sector and to ensure coordination among various government agencies" (GIDB, 2003). The organisation is an "over-arching body" for infrastructure development in Gujarat, encompassing a wide range of sectors including electricity, water, and transport. GIDB focuses on overall planning and coordination between various sectors by bringing together government decision-makers and private investors. The Board is headed by the Chief Minister of the State as well as Ministers connected with infrastructure and industrial development, and aims to take policy-level decisions that can speed project completion. 


\section{GEB OPERATIONAL PERFORMANCE}

Electricity shortages, breakdowns, load shedding, and low voltage have become chronic problems in India and thus the electricity sector is not able to collect sufficient revenue to pay for service improvements (Palmer-Jones, 1994). These problems can be found in all parts of Gujarat and one obvious consequence of poor operational performance and chronic under investment in the electricity sector is the shortage of electricity to meet demand.

\subsection{Generation}

Demand growth in Gujarat has outpaced capacity installation and demand side management efforts and the resulting gap is especially acute with respect to peak demand periods, when the shortfall grows to more than $15 \%$. As a result, GEB must institute widespread load shedding to balance the system. The most common scenario is for rural areas to be subject to rostering, thus most farmers have only 4-6 hours of electricity per day. The shortfall has also had an impact on industrial growth, retarding new investment or forcing companies to build captive generation capacity to supply their needs. Figure 3.1 displays both the peak deficit and the total energy shortages from 1995 to 2002.

Figure 3.1: Electricity Energy and Peak Demand Shortages in Gujarat, 1995-2002

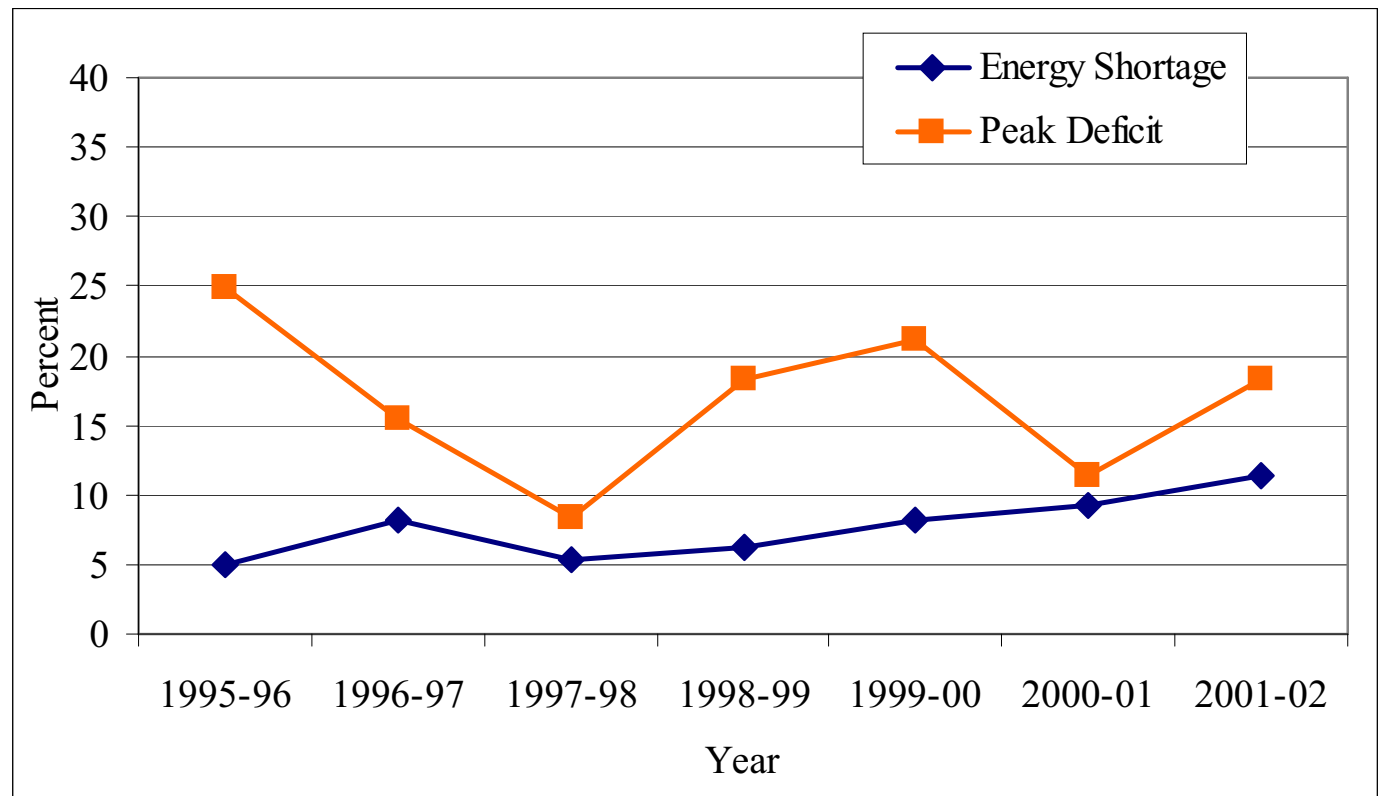

Source: (MoP, 2003) 
Table 3.1 quantifies the scope of the problem in the latest period and shows some improvement on the part of the GEB. Recent privatisation, captive capacity additions and improved output per plant at the GEB have reduced the shortfall but these problems are expected to continue into the future and severe electricity shortage in five western states, including Gujarat, will likely lead to electricity outages in the summer of 2003 (Kuber, 2003).

Table 3.1: Gujarat Maximum Demand and Plant Load Factors 2001-2003

\begin{tabular}{|c|rrr|}
\hline Period & $\begin{array}{c}\text { Max Unrestricted } \\
\text { Demand (MW) }\end{array}$ & $\begin{array}{c}\text { Max Demand } \\
\text { Catered (\%) }\end{array}$ & $\begin{array}{c}\text { Plant Load } \\
\text { Factor (\%) }\end{array}$ \\
\hline \hline April 01 - Jan 02 & 8476 & 80.4 & 67.3 \\
April 02 - Jan 03 & 9040 & 85.7 & 69.8 \\
\hline
\end{tabular}

Source: (CMIE, 2003)

The Plant Load Factor (PLF) indicates the proportion of the total plant capacity that is actually utilised to generate electricity. The plant load factor in Gujarat in 2002 was $69.8 \%$, in the range of OECD figures, up from $67.3 \%$ the previous year (see Table 2.8) (CMIE, 2003). Auxiliary consumption in GEB thermal plants was approximately $10 \%$ in $2000-01$ (GERC, 2000), which is well above the OECD benchmark of 3-5\%.

The merit order $^{5}$ of selecting plants for operation and electricity purchase is not strictly enforced in Gujarat. The GEB purchases its electricity from Central Generating Stations, Independent Power Producers and also from Captive Power Plants, other generation sanction holders and Non-conventional sources like windpower. The purchase of electricity has not been done on an economic basis and long-term contracts or politics have determined many of the dispatch characteristics. To begin to solve the problem, the GERC has ordered the GEB to implement merit order electricity purchases, a move that is expected to reduce electricity purchase from IPPs by $1 / 3$ (GERC, 2000). However, long-term contracts with the independent power producer (IPP) companies will likely prevent a rapid change to merit order dispatch and may drive electricity costs higher for the GEB. In August of 2003, however, the GoG began trying to coerce the independent power producers (IPPs) in the state to revise their PPAs. The goal is to reduce the cost of power and leave resources available to pacify the farm and political opposition with continued subsidies (Raghu, 2003). Captive power producers, who could supply electricity at lower marginal cost than GEB or federal capacity

\footnotetext{
${ }^{5}$ Merit order is the practice of purchasing electricity from generators with the lowest marginal cost first, thus minimising total power purchase costs.
} 
are often excluded, thereby resulting in technical and economic inefficiency, but this may change under the new Gujarat Electricity Act, as discussed in Section 4.

\subsection{Transmission and Distribution}

To improve sector profitability the issue of high T\&D losses, which are estimated at over 50\% in many Indian states and amount to more than \$6 billion annually (about 2\% of India's GDP), needs to be addressed. The T\&D losses, which have doubled every 3 years for the past decade, represent twice what the country spends on health and half its expenditure on education (CORE, 2002). The T\&D issue involves four parts, technical losses, distribution transformer problems, corruption and theft.

The drive to supply electricity to all rural locations has led to an overloading of low-tension lines, and the over extension of the length of the feeder lines. In addition, there has been inadequate investment in T\&D new capacity and maintenance. There has also been a strong bias towards investing in new generation capacity instead of upgrading the T\&D network (Kannan and Pillai, 2000). The longer lengths of the lines, higher currents travelling through them, and the high ratio of low-tension (LT) to high-tension (HT) lines ${ }^{6}$ have resulted in high technical losses. The all-India average of reported cumulative T\&D losses was $21.8 \%$ in 1997 and 18\% in Gujarat, figures that most likely under-report the theft of agricultural electricity load. By comparison, other developing countries reported much lower figures: China, 7\%; Thailand, 10\%; and Argentina, 14\% (Kannan and Pillai, 2000). OECD figures range between $6 \%$ and $9 \%$.

On December 31, 2002 the western district, Kachchh distribution circle in Gujarat had 11,810 distribution transformers in operation. In the first nine months of 2002, 2906 of those failed, requiring replacement or major repairs (Patel, 2003). Thus an annualised failure rate of 30\% is being experienced. For Gujarat as a whole the failure rate is $24 \%$ or approximately $2 \%$ per month, which translates into a significant expense on top of electricity theft and technical line losses. Each $25 \mathrm{kVA}$ distribution transformer costs approximately Rs 45,000 to replace and larger capacity $63 \mathrm{kVA}$ transformers cost Rs 80,000 (Shah a, 2003).

\footnotetext{
${ }^{6}$ Gujarat has $30266.7 \mathrm{~km}$ of EHV/HV lines, $139984 \mathrm{~km}$ of 11/22 kV lines and $199416 \mathrm{~km}$ of LT distribution lines, for a HT:LT ratio of 0.854 .
} 
The main causes of transformer failure are the large number of unauthorised loads and the over-capacity of agricultural motors connected to each. High loading, especially for rostered rural areas, occurs because motors and other heavy loads are left switched on to immediately take advantage of the electricity when it is turned back on in the area. Thus, the load jumps from zero to high levels with no lag time and the transformers burn out. Ultimately, failed distribution feeders result in electricity outages. Aggregate figures for the GEB show total transmission interruptions of 398 hours in 2001-02 and a weighted average availability ratio of 98.1\% from 1999-2002 (ICRA, 2003). The GERC has ordered the GEB to reduce outages and improve voltage and frequency levels (GERC, 2000).

\subsection{Supply}

Rent seeking and corruption occur at both the macro level and in the form of petty corruption in the Indian electricity sector. The petty forms have been examined by field level surveys conducted by Transparency International, India (2002), which reveal the scope and depth of corruption for the average Indian. On the micro level, corruption in the electricity sector alone affects $5.9 \%$ of the Indian population each year. Most cite 'improper supply of electricity' and 'payment of excess bills' as the key corruptions faced. About 50\% of survey respondents who had interacted with the power sector in the past year had to bribe the office staff in order to ensure electricity supplies to their residence (TII, 2002). The key actors in corruption in this sector are linesmen (37\%), officers (24\%), meter readers $(23 \%)$ and billing clerks $(22 \%)$. The highest incidence of this experience was in the West Zone of India (72\%), which includes Gujarat (TII, 2002).

In many villages and poor urban areas, local 'strong men' control access to electricity by selling illegal connections or brokering with the local GEB linemen to allow legal hook-ups. This corruption is then protected by influencing the local MLA to ensure that any reformminded GEB engineer cannot enforce electricity theft laws. In some cases, armed thugs are employed to drive away GEB theft reduction teams (Srivastava, 2003). This process is similar to the private security forces or goondas that are used by local politicians to enforce and perpetuate corrupt relations (Harriss-White and White, 1996). 
Corruption has manifested itself in the SEBs' reporting high transmission and distribution or auxiliary losses when in fact more than half of the 'lost' electricity is theft. Little or no metering and poor billing and collections add to the difficulties of recover costs. In many cases, managers are involved directly in the sale of electricity to industrial facilities (Morris, 2002). "There is obviously mis-reporting going on within the GEB, to the private benefit of GEB engineers and industrial (especially small industry) consumers who are the principal beneficiaries" (Morris, 1999):10). For example, SEB managers claim extra compensation from the government by over-reporting agriculture use and then keeping the difference for themselves, which can amount to more than Rs $2 / \mathrm{kWh}$. The direct subsidisation of the sector is an open invitation for corruption and illegal sales because the losses are transferred to the government balance sheet and there is no hard budget constraint. Recent liberalisation of ownership efforts in Orissa have failed to correct the problem because they do not structurally change the subsidisation pathway (Thillai, 2000; Thillai, 2003).

Morris (2002, a) argues for an incremental change that implements a system of direct subsidisation using coupons or vouchers that would better control the leakages from the system. For example, each eligible farmer would receive a base level of subsidised electricity coupons; any consumption above this level would have to be paid for at the commercial rate. However, this solution could result in a corrupt voucher program with politicians crafting the system to ensure they are able to hand out the largesse, thereby reproducing the client-patron relations that dominate public goods distribution in India. Rent-seeking and corruption are endemic in both developed and developing economies. The difference in the developing world is that the corruption is more extensive, includes a myriad of forms and can be more damaging for growth (Khan and Jomo, 2000).

\subsection{Financial Status}

The GEB's finances have been undermined by the high levels of theft and non-payment of bills. In addition, the large agriculture subsidy and the misreporting of industrial or commercial users as agricultural demand that in effect represents illegal electricity sales are further reducing revenues. Three indicators of financial health used by ICRA, (formerly, Investment Information and Credit Rating Agency of India Limited), for the SEBs are: the subsidy rate required from the state government to achieve a $3 \%$ return on capital; board debt 
levels; and the ratio of revenues to operating costs. In each case, the GEB's position has deteriorated. To cover the revenue shortfall, the Government of Gujarat (GoG) pays the GEB an operating subsidy each year. Table 3.2 shows the level of subsidy required (i.e. payable) to bring the GEB into the black and the total subsidy actually paid.

Table 3.2: Subsidy Levels for the GEB in million Rs, 1998-2001

\begin{tabular}{|l|rrr|}
\hline \multicolumn{1}{|c|}{ Year } & 1998-99 & 1999-00 & 2000-01 \\
\hline \hline Subsidy Paid & 14840 & 12330 & 36690 \\
Subsidy Payable & 5100 & 23310 & 26700 \\
Ratio & 2.91 & 0.53 & 1.37 \\
\hline Average Ratio & \multicolumn{3}{|c|}{$\mathbf{1 . 1 6}$} \\
\hline
\end{tabular}

Source: (ICRA, 2003)

Actual profit and loss values in Figure 3.2 show the deteriorating 'bottom line' result of a broken system of subsidised tariffs that do not cover the cost of supply and little operational accountability.

Figure 3.2: GEB Profit and Loss Before Subsidy, 1992-2001

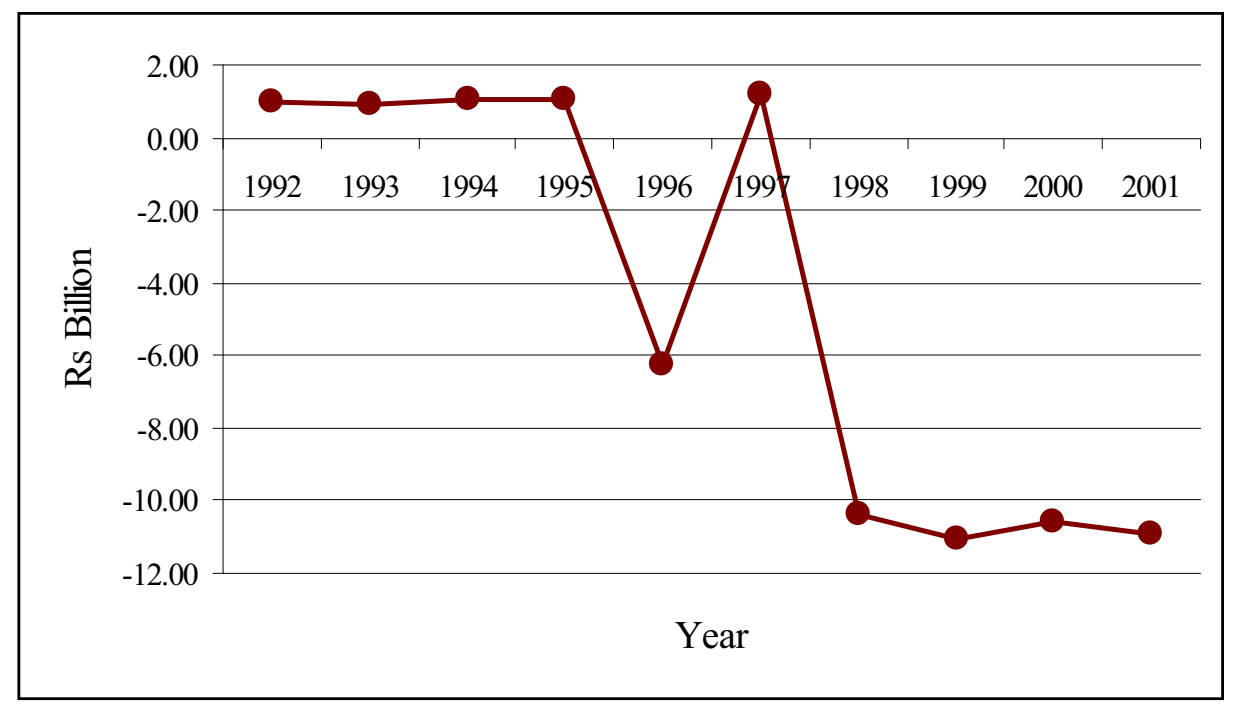

Source: (PC, 2002)

The GEB losses in 2001 were Rs 10.7bn (\$227 million) and have shown little improvement since. Thus the Gujarat system is virtually bankrupt and will continue to lack the resources to provide adequate levels of service, especially to rural areas in the future. In sum, costs are rising while subsidised tariffs, theft and non-collection of bills continue to reduce revenues. 
Table 3.3 shows the annual growth rate in the cost of electricity for Gujarat compared to the all India average.

Table 3.3: Cost of Electricity for GEB and all-India Average, 1996-2001 (Rs/kWh)

\begin{tabular}{|c|c|c|c|c|c|}
\hline Area & $\begin{array}{r}\text { 1996-97 } \\
\text { Actual } \\
\end{array}$ & $\begin{array}{c}1997-98 \\
\text { Actual } \\
\end{array}$ & $\begin{array}{c}\text { 1998-99 } \\
\text { Actual } \\
\end{array}$ & $\begin{array}{c}1999-2000 \\
\text { Provisional } \\
\end{array}$ & $\begin{array}{c}\text { 2000-01 } \\
\text { Rev. Esimate } \\
\end{array}$ \\
\hline GEB & 2.07 & 2.48 & 2.77 & 3.13 & 3.54 \\
\hline Nominal \% Growth/yr & & $19.4 \%$ & $12.0 \%$ & $13.0 \%$ & $13.2 \%$ \\
\hline All India Average & 2.16 & 2.40 & 2.63 & 3.05 & 3.27 \\
\hline Nominal \% Growth/yr & & $11.2 \%$ & $9.7 \%$ & $16.0 \%$ & $7.2 \%$ \\
\hline
\end{tabular}

Source: (ICRAb, 2003)

The average tariff in the agriculture sector is Rs $0.17 / \mathrm{kWh}$ (in 2000) and this category of demand has grown to nearly half of all electricity billed. Thus, the revenue ratio has slipped from $96 \%$ in 1998 to $83 \%$ by 2001 , while the debt level has increased from Rs 71.9 billion in 1999 to Rs 91.8 by 2001. At the same time, the resources allocated to the GEB for capital expenditure have decreased in the planning process. In the $7^{\text {th }}$ plan, 1985-90, Gujarat allocated $26.4 \%$ of plan resources to the electricity sector; but this has now slipped to $10.8 \%$ in 2001-2. The reductions in Gujarat also put it below the Indian average share, which was $12.2 \%$ in $2001-2$.

Like many other Indian states, Gujarat has been using the GEB to help finance public spending by delaying payments to central government electricity suppliers, such as NTPC. These arrears, which now total Rs 11.2 billion (\$238 million) (MoP, 2003), allow the state government to delay subsidy payments and extend budgetary outlays to other sectors, essentially financing the electricity sector through the central government that is guaranteeing the debts of the NTPC, REC, etc.

Of direct concern for the electricity sector, is the deterioration of the financial position of the Gujarat government, which because of a steep increase in revenue deficits, now has a high level of debt (ICRAa, 2003). The adverse revenue impact due to disturbances in parts of Gujarat, such as the earthquake of 2001 and the riots of 2002, as well as continued high losses at the Gujarat Electricity Board (GEB) and Gujarat State Road Transport Corporation has hit the state coffers hard. In 1995-96, the deficit was Rs 2.22 billion; which rose to Rs 67.32 
billion by 2001-02 on a total state expenditure of Rs 432.1 billion, meaning that $15.5 \%$ of spending was with borrowed funds (GoGa, 2003). The financial problems have made the case for reform in the electricity sector more urgent.

The other important measures of the state's financial position are the deficit and debt levels compared to state domestic product. The fiscal imbalance caused by high expenditures and low growth in tax and royalty revenue has resulted in a fiscal deficit that, as a percentage of net state output, has grown from $2.8 \%$ in $1995-96$ to an estimated $9.3 \%$ in $2001-02$. The level of debt has grown concomitantly, topping $32 \%$ in $2000-01$, growing to $38.8 \%$ in $2001-02$, and projected to increase to $44.4 \%$ of GSDP by March 2003. Considering all government debt instruments and guarantees in their totality, the percentage of outstanding liabilities to state output was 51\% in March, 2001 (ICRAa, 2003). Continuing current high levels of subsidies that are allocated to the electricity sector would put a further strain on the Gujarat government's finances.

\subsection{Sources of Finance}

As a result of the poor financial position of the board and low budget allocation, the GEB is unable to finance new generation projects and struggles to keep up with maintenance on current generation plants and T\&D facilities. Sources of new finance for electricity projects are difficult to obtain, as related in the Economic Times of India in November 2002: "Fast deteriorating financial conditions of the state electricity boards are seen as a major bottleneck by the industry. The weak financial condition of the state electricity boards not only discourages new investment but also causes trouble for the existing [investment]. With weak financial positions of state electricity boards, banks have also started reducing their exposure to the power projects." For grid generation capacity additions two main options have been used in Gujarat, independent power producers (IPPs) and more electricity from the CPSU's (central public sector undertakings, i.e. government-owned utilities), such as the National Thermal Power Corporation (NTPC).

IPP investment in Gujarat and the Indian electricity sector more generally have been halted by a number of economic factors and by the chilling effect of the failed Dabhol Power Project, undertaken by Enron and Bechtel. The chief of Electricité de France (EdF) in India commented, "IPPs are finished. The system has clogged completely, [and] existing IPPs are 
struggling in almost every state where they are operating." He goes on to comment that there are examples from several states of cancelled power purchase contracts with IPPs, even over the objections of the MoP (Srivastava, 2002). In addition, the high cost of electricity from imported liquid- or gas-fuelled IPP generating stations has increased the costs of electricity acquisition of the GEB and reduced output for IPP plants. The international investor is now totally absent and local players are few because returns are small. Clearly, IPP investment will not be viable until the financial position of the SEBs is improved. The CPSU's are also short of electricity, and have allocated only marginal increases to Gujarat in recent years, and have stopped increases completely in 2002. While NTPC may offer some long-term relief as it adds capacity, other options will have to be considered. 


\section{POLITICAL ECONOMY OF ELECTRICITY IN GUJARAT}

The severe fiscal and electricity supply squeeze in Gujarat has helped to propel liberalisation and restructuring to the forefront of state politics, but there is a strong possibility that interest group politics may subvert the process or dilute its effectiveness. This section describes the forces involved in electricity regulation as well as the hurdles to change and explains why momentum is gathering for a more liberalised regulatory structure for electricity in Gujarat.

\subsection{Political Environment}

The upper classes (predominately high castes) in Gujarat account for $26 \%$ of the population, but occupy $75 \%$ of the middle class and $95 \%$ of the wealthiest class. This group has translated economic success into political clout by overwhelmingly supporting the BJP in the last election (Prakash, 2003). The BJP captured 51\% of the total vote in the December elections, securing 126 of the 182 seats in the state assembly and winning 79 of the 102 seats in the 13 riot-affected districts, which are in central, north and south Gujarat. The Congress Party finished with only $38 \%$ of the vote, yielding 51 sets in the new assembly. The election results were not evenly distributed, with Congress doing relatively well in the more rural Saurashtra region (western Gujarat), and the BJP victorious in districts affected by the riots in early 2002 (Prakash, 2003).

The majority of the legal funding for the BJP comes from the trader and business class ranging from retailers to industrialists (Joshi, 2003). The BJP is perceived as a party of the business people, in contrast to Congress, which is seen as a pro-poor party. The election victory returned BJP Chief Minister Narendra Modi to office and has set the stage for a consolidation of power in many areas of the economy (Dasgupta and Mahurkar, 2002). The electricity sector will likely see a break in the logjam of regulatory reform and policy inaction that characterised the run-up to the elections.

Gujarat Minister of State for Energy and Petrochemicals, Saurabh Patel, introduced a number of measures to reduce the GEB's annual deficit of Rs 20 billion as follows: 
i. A target of Rs 800 million is to be obtained from reducing electricity thefts;

ii. Planned imposition of a $10 \%$ cut on GEB's administrative expenditure;

iii. Debt restructuring will reduce interest rates on GEB loans with the Industrial Development Bank of India (IDBI); and

iv. Planned renegotiation of power purchase agreements to decrease per unit supply costs (PTI, 2003).

The GoG has shown commitment to initiating reforms in its electricity sector in line with the parameters laid down in its memorandum of understanding (MoU) with the MoP. The progress achieved so far against the said parameters has been satisfactory. The GEB's financial situation has, however, been constrained by the lack of sustainable subsidy support due to the pressures on the State government finances (ICRAa, 2003). The counter interpretation of the past few years is offered by Morris $(2002$, a) when he claims that the reform efforts are stymied in Gujarat because of GEB bureaucratic resistance and the government's inability to confront the subsidy issue, with deference to political expediency.

To summarise, Figure 4.1 displays the different forces acting for and against electricity reform in Gujarat. This tool has been used for many decades within management and assumes a starting state of equilibrium for a policy environment. The equilibrium is a result of the balance between driving forces that push for change and restraining forces that act against change. In order to make change happen, the balance of these forces must be altered so that the equilibrium moves.

\subsection{Centre and State Electricity Reform Bills}

The Electricity Act 2003, originally proposed in the 2001 session of the Lok Sabha, was adopted in May of 2003. The Electricity Act replaces the three previous statutes for the sector (1910, 1948 and 1998) and lays out a bold direction for electricity reform while simultaneously removing the political cover the states have been hiding behind to slow electricity reform. Active participation by small operators is encouraged in many parts of the Electricity Act (discussed in more detail in Sections 4.4-4.6) as well as a direct injunction to phase out cross-subsidies and ensure open access to the transmission and distribution system. 
Figure 4.1: Forces in the Gujarat Power Sector Reform Process

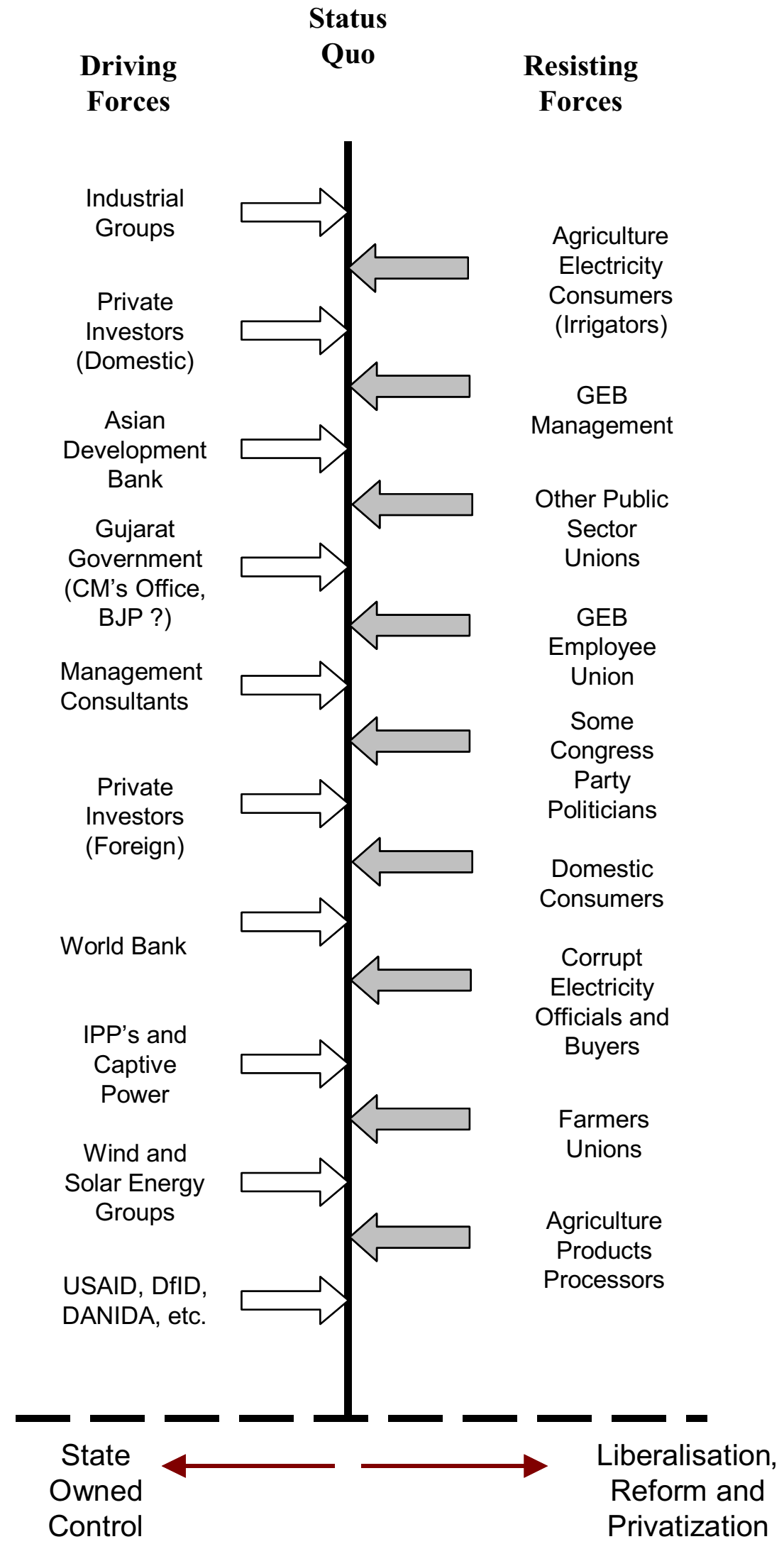


The Electricity Act has been criticised for not addressing the agriculture subsidy issue, except to require that it be explicitly paid through the state budget, but the problem of differential power prices between sectors remains. This will continue to provide incentives for pricearbitrage, manifested as corruption and theft (Morris a, 2002). As a counter, the act does include several measures to combat theft, such as special courts for prosecuting offenders quickly. It also reduces some regulatory uncertainty by decreasing the number of approvals needed for new captive and rural energy projects, but it does not adequately reduce the complex overlapping structure of regulation from the centre to the state bodies, or the large number of approvals needed for some power projects which do not sell power across state lines. The outcome on the ground may be the continuation or expansion of some forms of corruption, a distinct possibility when considered within the corruption framework presented by Khan that stresses the propensity of liberalisation efforts to create new spaces for corruption instead of streamlining systems (Khan and Jomo, 2000).

Passage of the Electricity Act 2003 at the federal government level has paved the way for the GoG to adopt the Electricity Industry Reorganization and Regulation Act 2003 (GoG, 2003) in June 2003 ('the Gujarat Electricity Act'). Chief Minister Modi has kept the electricity and energy portfolio within his office, a sign of political commitment to implementing the act with some speed. The state of Orissa provides a precedent, where the decision to keep the sector in the Chief Minister's portfolio and a strong commitment from him, pushed the bill through in 1995 and led to many tangible changes in the sector (Thillai, 2003).

The Gujarat Electricity Act, first proposed in 2001, is part of the continuing effort to reduce the GEB's financial burden on the state coffers. The Modi government had already decided to act aggressively to end some domestic subsidies in the electricity sector starting March 1, 2003 with an order to scrap the $25 \%$ discount to domestic consumers with monthly demand of $100 \mathrm{kWh}$ or less. The GoG will save over Rs 1.25 billion as a result (TNN, 2003). This announcement is seen by the industry experts as a sign that more sweeping electricity reform may be implemented in the coming year and could be the precursor to the removal of additional electricity subsidies to the farm sector (TNN, 2003).

Gujarat has thus far accomplished three main goals since the 1991 push for sector reforms:

i. SERC-constituted, functional, first tariff order issued; 
ii. Reform Law approved by Government of India and adopted in the Gujarat State Assembly; and

iii. Memorandum of Understanding (MoU) signed with Government of India.

In practice, the progress has been slow. The Asian Development Bank has sanctioned loans of $\$ 350$ million under the Gujarat Power Sector Development Program. The funds will be split between a $\$ 150$ million program loan to the state and $\$ 200$ million as a project loan to the GEB. The loan is part of a wider ADB effort to encourage and support reform efforts across India. However, Sebastian Morris commented that the goal of the program has largely been ignored in practical terms, as many of the reforms undertaken have been on paper only and have not liberalised the sector (Morris c, 2002). A good example of this is the 'privatisation' of GEB generation assets under the GSECL.

The Gujarat Electricity Act has many shortcomings, including: not laying out a new captive electricity policy; not confronting the agriculture subsidisation issue other than to require more transparency; and allowing but not directing a change in the ownership of GEB assets. The main changes implemented would likely be to trifurcate the GEB into generation, transmission and distribution companies. In addition, the Gujarat Act has language that would guarantee the transfer of current GEB employees to the new entities, with no changes allowed for 12 months, and after that time only with the approval of the State government. The other concern is that the act does not adequately protect the regulator from capture by political interests because the Chief Minister can effectively remove a commissioner at any time.

The Gujarat Model of proposed electricity deregulation, now in the hands of the GERC, involves setting up seven distinct distribution companies from the sell off of GEB assets. Morris details the market ramifications of this move and claims that any change that would bring about more accountability would help stem the losses from the electricity system (Morris, 2000). However, the break-up of GEB distribution may further dilute the technical and administrative capacity that exists in the state, leading to further problems, especially if the new distribution companies are privatised on paper only and do not have a dynamic change of ownership and management. 
The GEB is working hard to protect its interests within the legislation, and the recent report by the GERC that defends the level of agricultural use suggests that the GEB has created the conditions that will allow it to maintain its continued dominance in the sector. Counterbalancing the GEB political muscle are the active industrial and consumer groups such as the Federation of Gujarat Industries, Baroda; Gujarat Stainless Steel Rollers Association, Ahmedabad; Gujarat Chambers of Commerce and Industry, Ahmedabad; Gujarat Alkalies and Chemicals Limited, Bharuch; and Farmers of North Gujarat and Kachchh Area.

The other aspect of the new legislation is the focus on reducing electricity theft. Andhra Pradesh (AP) and West Bengal have both passed stringent new anti-theft legislation for the electricity sector, and Gujarat has included these measures in the 2003 Act. The Gujarat Act establishes special courts for the quick prosecution of electricity theft and allow the GEB to go directly after landlords instead of trying to prove theft by individual tenants (Srivastava, 2003). While it is too early to tell if the new measures have been successful in AP and West Bengal, any new tools whereby the GEB can reduce theft can only benefit the revenue stream. The continued involvement of GEB officials in theft will, however, probably not be seriously threatened; and therefore only 'smaller fish' or the HT consumers without political cover will be prosecuted.

\subsection{Tariff Adjustments}

In 2001, the GERC tariffs were about average in each sector, but industrial tariffs were 0.70 $\mathrm{Rs} / \mathrm{kWh}$ above the all-India average. Table 4.1 shows the rates for several comparable SEBs and a baseline for Gujarat tariffs.

The Union electricity secretary, R. V. Shahi, has called for the removal of free electricity and cross-subsidies in the electricity sector in order to improve the electricity scenario in the country. "Free electricity to any sector, be it agriculture or household, should be done away with in a fast process, while the process of eliminating cross subsidies may be a gradual process," (TNN, 2002). The GERC has recently established higher tariffs for agriculture users and is undertaking efforts to encourage the installation of meters (Sharma, 2003). The Commission has stipulated that all new connections must be metered and has set a goal of metering all connections within three years. The previous agriculture tariff was set at an 
equivalent of approximately $0.16 \mathrm{Rs} / \mathrm{kWh}$ using the per horsepower/year tariff scheme. The GERC order mandates a minimum charge of $0.50 \mathrm{Rs} / \mathrm{kWh}$ to increase cost recovery (Sharma, 2003). However, this measure is unlikely to reduce the margin, and therefore the incentives for corruption, between agriculture and the new industrial and commercial tariffs, which are above 4.0 Rs/kWh. See below for each sector's new tariff levels (GERC, 2000).

Table 4.1: Average Consumer Tariffs for Selected SEBs (Revised Estimate), 2000-2001

\begin{tabular}{|c|c|c|c|c|c|c|}
\hline \multirow[t]{2}{*}{ SEB } & Domestic & Commercial & Agriculture & Industrial & Railways & \multirow{2}{*}{$\begin{array}{c}\text { Overall } \\
\text { Average }\end{array}$} \\
\hline & \multicolumn{5}{|c|}{$(\mathrm{Rs} / \mathrm{kWh})$} & \\
\hline Andhra Pradesh & 1.74 & 4.26 & 0.15 & 4.39 & 4.68 & 2.11 \\
\hline Delhi (DVB) & 1.50 & 4.16 & 0.50 & 4.25 & 0.00 & 2.97 \\
\hline Gujarat & 2.43 & 4.48 & 0.39 & 4.40 & 5.06 & 2.15 \\
\hline Karnataka & 1.98 & 5.72 & 0.31 & 4.10 & 4.14 & 2.17 \\
\hline Kerala & 0.81 & 4.36 & 0.67 & 2.25 & 1.98 & 1.89 \\
\hline Madhya Pradesh & 1.60 & 4.31 & 0.07 & 4.38 & 5.06 & 2.05 \\
\hline Maharashtra & 2.48 & 4.56 & 0.82 & 4.20 & 4.20 & 2.71 \\
\hline Rajasthan (Transco.) & 1.91 & 4.30 & 0.46 & 3.93 & 4.06 & 2.25 \\
\hline Tamil Nadu & 1.69 & 4.02 & 0.01 & 3.80 & 3.85 & 2.24 \\
\hline West Bengal & 1.49 & 2.37 & 0.58 & 3.20 & 3.70 & 2.24 \\
\hline Average : All SEBs & 1.84 & 4.07 & 0.35 & 3.68 & 4.36 & 2.26 \\
\hline
\end{tabular}

Source: (PC, 2002)

For agriculture, the metered tariff is currently $0.50 \mathrm{Rs} / \mathrm{kWh}$, but under the Tatkal Scheme, agriculture applicants can get a new connection with express service, but are required to pay a metered rate of $0.70 \mathrm{Rs} / \mathrm{kWh}$. Existing connections without meters can continue to pay the HP (horsepower) based tariff; however, the rate has been increased to Rs 1680/per BHP/annum. The increase in the HP based tariff is substantial, both because the old rates were fixed in 1986 with no upward revision and because is provides an incentive to switch to metered supply. The HP tariff rate corresponds to an average cost per unit of $0.97 \mathrm{Rs} / \mathrm{kWh}$, which is still lower than the marginal cost of $2.10 \mathrm{Rs} / \mathrm{kWh}$ busbar incurred by GEB on average for all power plants.

For commercial users, the October 2000 GERC ordered rates are $3.60 \mathrm{Rs} / \mathrm{kWh}$ for the first 50 units per month, then $4.20 \mathrm{Rs} / \mathrm{kWh}$ for the next 100 units per month and $4.70 \mathrm{Rs} / \mathrm{kWh}$ for the remaining units per month. The sector will continue to provide a cross-subsidy for domestic and rural users. Residential consumers are subsidised, but because they have recently lost the $25 \%$ discount on the first 100 units $(\mathrm{kWh})$ of electricity (TNN, 2003), they now pay rates of $2.70 \mathrm{Rs} / \mathrm{kWh}$ for the first 50 units and $3.0 \mathrm{Rs} / \mathrm{kWh}$ for the next 50 units. The next 100 units 
are priced at $3.60 \mathrm{Rs} / \mathrm{kWh}$, followed by $4.10 \mathrm{Rs} / \mathrm{kWh}$ for $200-300 \mathrm{kWh} / \mathrm{month}$. Above 300 $\mathrm{kWh}, 4.70 \mathrm{Rs} / \mathrm{kWh}$ is charged (GERC, 2000).

The basic industrial sector tariff is split into two parts: energy charges and time of use fees. The energy charges are graduated; up to $1000 \mathrm{KVA}$ contract demand, users are charged 3.80 $\mathrm{Rs} / \mathrm{kWh} / \mathrm{month}$, while above $1000 \mathrm{KVA}$ contract demand, the rate climbs to 4.10 $\mathrm{Rs} / \mathrm{kWh} / \mathrm{month}$. In addition, 'time of use charges' are levied on consumers having contract demand or actual demand of $500 \mathrm{kVA}$ and above. For energy consumption during the two peak periods, (7:00 - 11:00 AM and 18:00 - 22:00 PM), 0.75 Rs $/ \mathrm{kWh}$ is charged. The tariff revisions result in relatively large increases for commercial and industrial LT customers. Table 4.2 shows the breakdown for each category.

Table 4.2: Consumer Category Percentage Increase in Tariff under GERC order 19-1999

\begin{tabular}{|l|r|}
\hline \multicolumn{1}{|c|}{ Category } & \multicolumn{1}{c|}{ \% } \\
\hline \hline Residential & 9.78 \\
Commercial & 13.37 \\
Public Lighting & 10.42 \\
Water Works & 9.32 \\
Industrial L.T. & 14.20 \\
Industrial H.T. & 4.77 \\
Railway Traction & 3.77 \\
Surat Electricity Co. & 7.58 \\
Ahmedabad Electricity Co. & 0.60 \\
\hline
\end{tabular}

Source: (GERC, 2000)

In comparison, the cost of captive power ${ }^{7}$ for HT customers is between $2.5-3.5 \mathrm{Rs} / \mathrm{kWh}$, depending on the technology and fuel used (Shah a, 2003). The $25 \%$ average price premium of the GEB tariff provides a strong incentive for new captive power plants and distributed generation for industry. However, the subsidised tariffs for agriculture and domestic consumers undercut the economic viability of similar projects for those sectors.

\footnotetext{
${ }^{7}$ Captive power is operationally defined in Gujarat as generating capacity built and owned by private companies for their own use or for sharing with nearby commercial concerns.
} 


\subsection{Captive Power Policy}

In 1998, Gujarat had 1505 MW of captive power installed capacity, which was $12.2 \%$ of the total. More than $1200 \mathrm{MW}$ of this was concentrated in four industries: chemicals, minerals, metals and textiles (PLR, 1998). Captive power now accounts for nearly 20\% of the total electricity produced in Gujarat, a response to the poor quality supply and high industrial tariffs from the GEB. The issue of captive power in Gujarat has been a contentious one for the past two decades. The tension arises from the Gujarat government's desire to allow for the cheapest and most reliable supply of electricity for industry while simultaneously not allowing the most lucrative load base for the GEB to abscond (Shah a, 2003). The GEB itself does not encourage captive power and has thwarted a number of such projects to maintain their customer base. One example is the Amul Food and Beverage Company, which applied to install a gas-fired electricity generation plant in Anand but was not allowed to sell electricity to third-parties, thus making the plant uneconomical (Shah a, 2003).

Included in the captive power policy framework is the construction of grid-connected large wind turbine farms. Wind farm projects in Gujarat have been numerous since the introduction of incentives in 1993, such as $100 \%$ capital depreciation in one year, sales tax exemption on wheeled electricity ${ }^{8}$, and wheeling charges of $2 \%$ to designated cross-owned facilities ${ }^{9}$. However, low buy-back rates from the GEB, around Rs $2 / \mathrm{kWh}$ have undercut windpower generation (Amin, 1999). The result of these policies was that inexperienced companies rushed to build windfarms for the tax benefits rather than for the long-term production of electricity. In one case, a company bought second-hand turbines from California and installed them in a coastal location that was ill suited to the technology, thus undermining the capacity factor of the array. The investment was intended to capture the tax write-off, not produce electricity (Patil, 2003).

The captive power policy in Gujarat mandates that any industrial undertaking to set up a captive power plant requires the consent of the Gujarat Electricity Board (GEB) under section

\footnotetext{
8 Wheeling electricity is an agreement to provide power at a certain time via the T\&D grid, effectively transferring power from a generator to a buyer for a price, but the actual power is homogenous in the grid and not separated. Wheeling charges are levied by the T\&D owner (in this case GEB) to transfer the power.

9 Wind farm owners are only allowed to wheel electricity to industrial units that are under the same ownership, thus, thirdparty sales are effectively prohibited.
} 
44(1) of the Electricity (Supply) Act, 1948. The policy, however, has many stipulations that make it difficult for private players to enter the electricity market. Banking ${ }^{10}$ of electrical power with GEB is not permitted and capacity is limited to two times the consumers demand. The minimum quantity of electricity to be wheeled must be more than $5 \%$ of the capacity of the captive power plant or $5 \mathrm{MW}$, whichever is more, and the supplying company must consume at least $50 \%$ of the generated electricity. With wheeling, the GEB imposed a system loss of $10 \%$ for electricity delivered at EHV and $15 \%$ in case of electricity delivered at $\mathrm{HV}$, in effect deducting the amount from the recipient unit. The rate for purchase of surplus electricity is decided by GEB and parallel operation charges are added at the rate fixed by GEB. The complex regulations of captive power also involve pollution control boards and in the case of wind units involves approval from 12 different state government departments in Gujarat, plus arrangements with the centre agencies, such as IREDA and MNES (Amin, 1999).

These policies have reduced the building of captive capacity even though small industries have been starved for electricity in Gujarat (Morris a, 2002). For example Andani Exports gas-fired plant of $160 \mathrm{MW}$ was scuppered by a lack of approval from the government and GEB (Shah, 1999). Captive power has been given 'stepchild' treatment by the state regulatory authorities as evidenced by the high wheeling charges, difficulty in obtaining permissions to build and the inability to sell unused capacity except to the GEB at low prices (Rao, 2003). Fortunately for captive power users the new Gujarat and Indian Electricity Reform Acts depart significantly from previous policies by opening up regulatory space for captive power or distributed generation by ensuring open access to transmission lines and eliminating the surcharges levied by the SEBs. Instead of implementing a declared price for excess electricity that the GEB has to buy, similar to what the US Federal Electricity Regulatory Commission did under the 1978 PURPA Law, the new acts throw wide open the generation market for all classes of consumers and most industrial and commercial users are likely to respond by leaving the GEB. The old policy shifted costs to new entrants and protected the incumbent GEB, or whatever privatised forms emerged from its assets (Morris a, 2002). The new policy will place the SEBs in direct competition with a wide variety of energy service options and the "consumers [will likely] flee the stables" (Padmanaban, 2003).

\footnotetext{
${ }^{10}$ Banking of power allows a generator to send power to the grid when it is available and take power from the grid at another site without the actual times coinciding, but the mismatch is limited to six months in Gujarat for renewables.
} 
The previous policy on captive power in Gujarat was tolerable for large firms, or industrial groupings with the same owner, because larger plants allow allow economies of scale to be captured to spread fixed costs (e.g. capital and bribes for adequate licences) to be spread over a larger capacity and are eligible for tax allowances. However, for smaller industrial concerns wishing to build captive power plants or a firm seeking to sell excess electricity, the incentives were low. Wheeling charges and a hefty cross-subsidy tariff are levied on each unit sold to other industrial users. The option of building a large plant and selling excess to the GEB was undercut by a non-remunerative tariff (Shah, 2003).

The Gujarat government has also encouraged the establishment of electricity cooperatives in industrial estates. The capacity of a plant to service the estate can vary between 60 and 120 MW. The GoG offers land and tax concessions, and in some cases the GEB will buy excess electricity, thus increasing the plant load factor (PLF) and economic rationale for the project. Captive power allows the GEB to avoid investment in new T\&D facilities and expanding generation; however, the loss of high value industrial customers has damaged GEB finances.

In March 2003, GERC released a study by TERI on captive power policies, entitled "Third Party Sales (TPS) - Concepts, issues and recommendations for Gujarat", which lays out the case for liberalising the captive power policy to allow TPS to: HT industry, railways and other licensee's. The study recommends that all three categories be permitted to switch to a TPS regime to create competition in the bulk supply market (TERI, 2003). These draft rules, if implemented, would open up generation to a wide number of players; however, the issue of distribution has still not been directly addressed. For small generators and rural distribution companies the regulatory structures would remain cumbersome, as explained further in section 4.6.

\subsection{Micro-distribution Units and Single Point Supply}

Industry has responded to captive power policy hurdles with several innovative proposals and a healthy dose of political influence to try to reduce energy costs and improve reliability. The first option is to work with the GEB by establishing a single point of supply contract. In this scenario, the GEB provides electricity up to the distribution feeder and the industrial estate handles the distribution and billing for all members inside the estate. For example, the 
Baroda Industrial Development Corporation has applied for and received a licence from the GERC to act as the local supply company for its members by reselling GEB provided electricity (Sharma, 2003). The Gujarat Industrial Development Corporation (GIDC) has decided to undertake a similar operation and the model is likely to spread to other industrial estates where the GEB can guarantee a reliable supply. However, many industrial units and estates cannot get this level of service and must opt for a captive plant to fill their needs. In this case, heavy political pressure and/or corruption are used to secure captive power plant permits.

For domestic consumers, the success of the industrial model may portend a similar arrangement for towns and villages. For example, a micro-distribution company could run the electricity system in a town or set of villages by buying electricity from the GEB at a single point of supply that is metered, and then resell it to consumers. The aim would be to allow for bulk power purchase to lower the costs for consumers and allow the GEB to gain higher revenues because of single point supply and easy metering. The main obstacle to this approach is the level of electricity theft in rural and semi-urban areas. The incentives to switch to a legal and regular supply are too low for most domestic consumers. The Rural Development Institute in Anand, Gujarat is now doing a study of the micro-distribution approach and has undertaken to identify one village in the five regions of Gujarat for trials (Sharma, 2003).

\subsection{Enabling Rural Distributed Generation}

The provision of electricity in rural areas lends itself to broad definitions of regulation, and thus comes under the auspices of multiple regulators. Many de facto regulators exist for rural institutions that are or may become involved in running electricity systems. For example, rural co-operative societies for electricity are regulated not only by the SERC, but also by the state level codes administered by a Registrar for all co-ops (Karlson, 2002). The same is true for consumer-owned, community-based organisations, which have state rules and registration requirements. In both cases the state authorities can intervene if the societies are found in violation of their originating statutes or have accounting irregularities. 
Unfortunately, there is no clarity in Gujarat law on separating the jurisdiction, so rural organisations that supply electricity will fall into many different regulatory regimes depending on their size and scope. However, Gujarat does have a strong tradition of cooperative societies that may serve as the backbone of rural efforts in electricity. The Amul Corporation, which produces dairy products for sale across India and for export, has its roots in milk cooperatives in Gujarat.

One example of a successful electricity cooperative in Gujarat is in Kodinar, which is the result of excess electricity from Gujarat Hi-Tech Industries Ltd. In 1987, a 20 million calorie per hour pulverised-coal and furnace oil fired kiln burner plant was installed, and the excess heat is used to make electricity for the town. Gujarat Ambuja Cement Ltd. also has a 2500 tonnes/day plant at Kodinar that consumes large amounts of electricity. The co-op model is more prevalent in Andhra Pradesh, where nine societies provide electricity to more than a half million customers and have annual electricity sales of more than $450 \mathrm{GWh}$ (Karlson, 2002). In some cases the co-ops are not well run, but the largest one in Andhra Pradesh, in Sircilla, was found to have almost complete meter coverage, and had better than $80 \%$ on-time bill collection. The co-op also aggressively enforced non-payment with disconnection and has been steadily expanding its customer base, with new connections being made with short waiting periods. The regulation of the Sircilla co-op is accomplished through registration under the state act that governed co-operative societies in AP, as well as a licence from the AP Electricity Regulatory Commission (APREC). The latter sets both the bulk supply and retail tariffs that can be charged, which could conflict with the financial regulation that the state ministry for co-ops imposes.

More recently, the West Bengal Renewable Energy Resource Development Agency (WBREDA) has committed to installing $20 \mathrm{MW}$ of decentralised electricity systems by 2011. To accomplish this, WBREDA plans to use three different institutional arrangements: co-ops, societies and direct system ownership. In all three formulations WBREDA, as the capital supplier, will exercise control over all important decisions (Karlson, 2002). Interestingly, WBREDA does not use tariffs to charge its customers, but instead charges 'donations' as payment. This allows the service providers to avoid WBERC regulation and in effect makes the WBREDA the regulator for rural, off-grid systems. This type of arrangement may work in Gujarat, but the need to connect to the grid for back-up electricity supply may preclude this option and thus keep the GERC involved in regulation. 
The other useful model of rural electricity supply regulation is in Bangladesh, where the Bangladesh Rural Electricity Board has been given clear authority in the provision of electricity to the rural areas. The BREB obtains electricity from small IPPs as well as from its own operation of a $140 \mathrm{MW}$ plant. It has accomplished 100\% metering, $96.93 \%$ bill collection and aggregate T\&D losses of only 13\% (Karlson, 2002). It should be noted, however, that BREB has received more than $\$ 1.1$ billion in aid funds in the last 20 years, as well as technical assistance from the U.S. National Rural Electric Cooperative Association (NRCEA).

Overall, the differences between rural and urban electricity needs have been largely neglected in the current round of 'reform' legislation (Karlson, 2002). The scope of regulatory commissions for rural ventures is not clear, thus leading to overlapping jurisdictions with state society-regulating authorities. The electricity regulatory bodies in the states are also young and thus their influence on the growth of renewable electricity has been minimal. But the powers invested in the SERCs to mandate the procurement of renewable electricity, set wheeling charges, establish banking provisions, regulate third-party sales and write grid interconnection standards put the task well within their purview (Ramanathan, 2002). In the U.S. and Europe, instruments such as the Renewable Portfolio Standard (RPS) and the System Benefit Charge $(\mathrm{SBC})^{11}$ have been used with great effect to encourage renewable energy investments. The GERC is considering them as possible policy instruments in the future (Sharma, 2003). Both of these ideas have been also supported by the Chairman of the Power Trading Corporation (PTC) of India, T.N. Thukur, who goes on to claim that possibly overlapping goals of supplying electricity to rural areas can be accomplished economically through the use of distributed generation systems (Thukur, 2002). The new GoI Electricity Act 2003, through an enabling provision, directly encourages states to develop stand-alone systems based on renewables, but it will be the SERCs that must put this intention into practice.

Passage of the new Electricity Acts at the centre and state level has opened up new opportunities for rural power distributed generation. Cooperatives and associations, such as local councils and NGOs can now operate captive plants without special permissions and the

\footnotetext{
${ }^{11}$ RPS, known as ROCs in the EU are used to specify a minimum renewable requirement in the total energy mix offered by a utility. For example, a $10 \%$ RPS would force $10 \%$ of all power sold to originate from a renewable source. SBC's are special tax levies on electricity sales that are set aside for renewable energy and energy conservation projects.
} 
SERCs are directed to phase in open access of the grid within one year. These measures, if taken up aggressively by the GERC will enable a new set of rural energy solutions. Couple this with the capital support provided by the REC, and the situation is ripe for a dynamic energy service sector to emerge. The key will be the ability of private energy firms to sell a value added product, especially with the low agriculture tariffs and the ease of power theft in rural areas. 


\section{SUMMARY AND IMPLICATIONS}

The regulatory uncertainty of the Gujarat situation, brought about by the myriad of opposing political forces and overlapping regulatory bodies, as well as the poor financial position of the GEB has left urban, rural and industrial consumers with either unreliable electricity supplies or indeed with no supply of any kind. However, the GoG willingness to move on subsidy reform and allowing private generators and distributors to enter the market, albeit in a limited way at present in the industrial sector, suggests that an alternative 'bottom-up' approach to reform may ultimately meet with more success than the stalled 'top-down' reform process that has focussed on privatising the GEB.

\subsection{An Alternative Solution}

Providing electricity to rural and some urban areas effectively involves a choice between two systems:

i. Increase electricity produced through central generation and then connect villages and urban areas via high voltage transmission systems; or

ii. Install captive power or distributed generation (DG) systems close to demand sites either in conjunction with a grid connection or an off-grid distribution system.

The first option involves using large power stations, which are able to capture economies of scale and spread fixed (capital and maintenance) costs and fuel costs over large electricity outputs and minimise variable costs by maximising thermal efficiency. The minimisation of long-run average electricity costs at the site of generation has therefore been the goal of most electricity planners.

Unfortunately, this approach may not be the most practical or economically viable, particularly in remote parts of the developing world, because the total cost of delivered electricity also includes transmission and distribution (T\&D) investment and the price of energy that is lost during delivery to the customer. A large centralised electricity plant not only requires significant capital investment in the plant itself but also in $T \& D$ to deliver the 
electricity. For the Indian electricity sector, long-term, adequate financing for new infrastructure has become increasingly difficult to obtain due to the poor financial position of the SEBs, which are all close to bankruptcy after years of poor management, inadequate tariff policies, widespread electricity theft and inefficiencies in the transmission, distribution and metering systems.

The economies of scale that once made large centralised power stations the only way to efficiently produce electricity have been undermined by small-scale generation technologies, with power ranges as low as $5 \mathrm{~kW}$, which may compete economically with grid connected, 1000+ MW central generating capacity. This trend is displayed schematically in Figure 5.1, reproduced from Casten (1995) where capital unit costs (in real $2001 \$ / \mathrm{kW}$ ) are indicated on the y-axis. However, this trend has been sharply reversed over the last decade as the year 2000 curve on the left edge of the plot indicates. Smaller capacity plants, including some distributed generation technologies, have capital unit costs $(\$ / \mathrm{kW})$ similar to those of the larger plants, represented by the cost curves above and to the right.

Figure 5.1: Changing Economies of Scale for Electricity Generation in Selected Decades

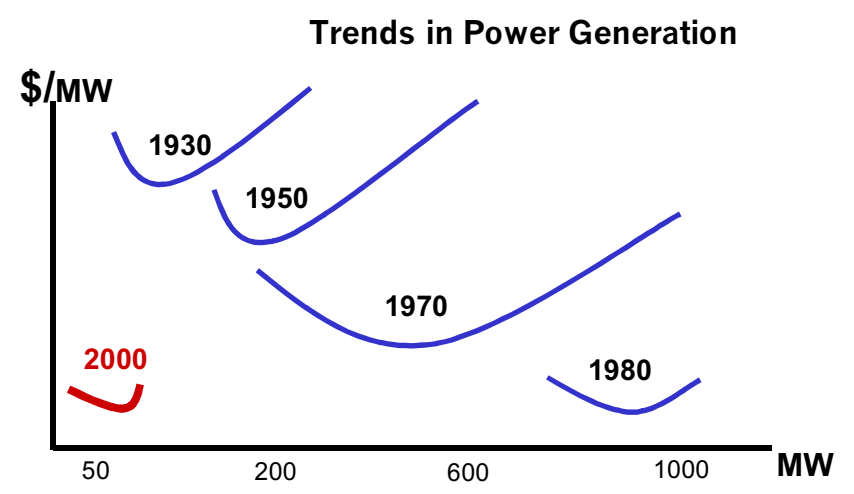

Source: based on (Casten, 1995)

The change in economies of scale for electricity generation opens up a wide range of opportunities for DG and may help provide electricity to rural areas that are currently underserved by traditional centralised grid systems.

The alternatives include generating technologies such as gas turbines, solar photovoltaic (PV) cells, fuel cells, wind turbines, biomass and biogas which, when appropriately applied, may 
provide electricity on a distributed basis more effectively than centralised generation. DG technologies are defined as those that allow the production of electricity at or near the point of consumption; they may open up a new era of electricity supply and challenge the conventional wisdom about generating plant economies of scale. DG plants typically have shorter planning and construction times, and require less lumpy expenditure of capital. They can be built in a modular fashion allowing for improved planning that more closely matches demand.

\subsection{Problems with Distributed Energy Systems in Gujarat}

Capturing the benefits from DG projects in Gujarat faces several serious obstacles:

i. Low, subsidised tariffs have reduced the incentive to seek alternatives in urban and rural areas. Farmers have had to pay so little for electricity, and domestic users have been able to steal free electricity for so long that the implementation of a pay-forservice model will have to overcome an expectation of free electricity. The tacit and explicit contracts of consumers to pay for service and the GEB to deliver quality service has been broken. As Morris (2002c) explained, "they pretend to supply electricity and the customers pretend to pay".

ii. There is little local capacity for maintenance or finance of small-scale electricity systems. DG projects require significant upfront capital investment, and the credit market does not exist for such projects. All financing is currently coming from NGOs, development banks or subsidised loans from IREDA/GEDA. Complicating the lack of credit in the sector is the large amount of regulatory uncertainty that pervades all new electricity projects. The basic market structure has not been determined in Gujarat and thus credit risk is pushed higher.

iii. DG projects suffer from a lack of economies of scale. High setup costs and the need for specialised engineering skills to build DG systems mean that many projects will need to be lumped together in order to reduce costs.

iv. Incentives from IREDA and REC may not be enough to overcome low tariffs that can be charged to rural consumers, and the projects will remain financially out of reach for communities. 
v. The MNES discourages use of diesels because of pollution concerns (Chaurey, 2002), and thus may restrict some DG projects that combine renewables with diesels.

vi. The GEB are unlikely to welcome DG because it would allow new entrants that may eventually 'cherry pick' the best loads, which is the same reason that captive power is discouraged now. The GEB is likely to be unwilling to provide a small IPP with the ability to wheel electricity, such as a DG project, because it breaks their monopoly, as evidenced by the GEB's refusal to buy electricity at long-run marginal cost even though electricity shortages exist.

\subsection{Conclusion}

The reform process in Gujarat has been criticised for being too slow and thus perpetuating a financial and performance crisis in the electricity sector. The reform thus far has not delivered a dynamic IPP presence and has likely stifled it in the future. Initiatives to increase competition have been blocked by many entrenched interest groups, not least of which is the GEB itself. However, the market has not failed to respond to changing conditions, even without a clear reform policy from the state government. The sector has evolved in a number of ways.

i. The high industrial tariffs that have been steadily increasing over the past decade, have led many larger industrial concerns to produce their own electricity. The build up of wind farms can partly be explained by this trend, but more importantly, the increase in fossil-fuel fired plants for electricity and process heat (now 20\% of total energy production) shows that investors in captive power have responded quickly and rationally to market price signals. The recently adopted reform bills have also taken captive power into account, which was especially timely since the GEB, often short of generating capacity, refused to take excess electricity from captive plants.

ii. The imposition of higher agriculture tariffs and the incentives to require metering of all loads has led to some success.

iii. The current market conditions may pave the way for more dynamic schemes in distribution. Already the GEB is supporting single point supply for industrial estates, and the continued high theft rates coupled with pressure from the GERC to reduce them, may force the same approach in commercial and residential settings, even if electricity supply is not privatised. 
iv. The continued dominance of a GEB that cannot supply the rural areas adequately may encourage more industrial partnerships with local communities for services. For example, the Reliance operation in Jamnagar has supplied low cost electricity to the nearby villages and taken over its distribution.

It can therefore be concluded that even without a competition-supporting and clear regulatory reform signal, the market has found several ways of supplementing the poor service and high prices of the GEB. To capitalise on the responses, small-scale captive plants and the support of cooperative or private distribution channels should be encouraged using the momentum of the two new reform acts, without which the sector will be unable to capture the dynamic gains from competition that local solutions can offer. A danger exists with the Gujarat Electricity Act 2003 (GoG, 2003) of implementing a reform piecemeal approach that may only change ownership while not attacking the core structural problems of high industrial tariffs, inefficient agriculture subsidies and the resulting lack of revenue from the sale of electricity. This paper argues that government policy should consider the more flexible nature of supply that DG can offer.

The use of distributed generation may help to reduce both technical and non-technical losses. Decreasing the amount of wire needed to deliver electricity reduces technical loss. The vulnerability of the system to non-technical loss may also be reduced by pushing the locus of control closer to the customer, thus changing the incentives and opportunities for theft through social, managerial, and technical means. For example, in South Africa, pre-paid meters and local distribution cooperatives have decreased theft and increased total tariff collections (Smith, 1998). Bangladesh has used local NGOs and a subsidiary of a Grameen Bank, Grameen Shakti, to bring more enforcement and control to the local level and reduce theft (Biswas, Bryce, and Diesendorf, 2001).

Distributed generation has a number of other technical advantages over centralised electricity production. Since electricity cannot be stored, supply must be matched in time and scale to demand; which means that there must always be sufficient capacity available to meet peak demand, even though that capacity may only be needed for a few hours per year. DG can be used to meet these demand peaks, thereby allowing electricity companies to delay investment in centralised generation, transmission, and distribution. Where growth is rapid, incremental 
DG investment may also be used to meet timing differences between large-scale investment and local load growth. The addition of generation at the ends of distribution grids can also help to improve the electricity quality, which would prevent damage to electrical equipment (Chaurey, Ranganathan, and Mohanty, 2002; MoP, 2002).

The regulatory uncertainty of the Gujarat situation, as well as the poor financial position of the GEB has left urban, rural and industrial consumers poorly served. The Indian Electricity Act has set an innovative direction for electricity policy in the country as a whole and now GERC can move aggressively on subsidy reform, theft reduction, and competition issues that will provide a stimulus for investment in small- and large-scale generation by the private sector at the local level, and allow more captive power for industry. By adopting an incremental and competition enhancing bottom-up, rather than top-down planning approach, the current roadblock on foreign direct investment and inevitable taint of corruption that has surrounded mega-projects in the past could be avoided. 


\section{REFERENCES}

Ahluwalia, M.S. 1999. India's Economic Reforms An Appraisal. In India in the Era of Economic Reforms, edited by N. Bajpai. Delhi: Oxford University Press.

Amin, A-L. 1999. Liberalization of the Indian power industry: wind power in Gujarat. Renewable Energy 16 (1-4):977-980.

Beall, J. 1997. The Political Economy of Solid Waste Disposal. PhD, Development Studies, London School of Economics, London.

Biswas, Wahidul K., Paul Bryce, and Mark Diesendorf. 2001. Model for empowering rural poor through renewable energy technologies in Bangladesh. Environmental Science \& Policy 4 (6):333-344.

Casten, T.R. 1995. Whither electric generation? A different view. The Energy Daily (September 7).

Chaurey, Akanksha. 2002. Fellow, TERI. New Delhi, December 8. Personal Interview

Chaurey, Akanksha, Malini Ranganathan, and Parimita Mohanty. 2002. Enhancing electricity access in rural areas through distributed generation based on renewable energy. New Delhi: Tata Energy Research Institute.

CMIE. 2003. Electricity Generation. Monthly Review of the Gujarat Economy, Center for Monitoring the Indian Economy.

Corbridge, S., and J. Harriss. 2000. Reinventing India. Cambridge: Polity.

CORE. 2002. India Electricity Distribution Reform Review and Assessment, Volume 1: Main Report. New Delhi: USAID.

Dasgupta, S., and U. Mahurkar. 2002. How Gujarat Voted. India Today, December 30, 55.

ESMAP. 2002. Energy Strategies for Rural India: Evidence from Six States. Washington, DC: World Bank.

Etienne, G. 2000. the Role of Electricity in India's Agriculture. In India's Energy, edited by P. Audinet, Shukla, P., Grare, F. New Delhi: Monohar.

GERC. 2000. Tariff Order No. 19 of 1999. Ahmedabad: Gujarat Electricity Regulatory Commission.

Ghosh, Sajal. 2002. Electricity consumption and economic growth in India. Energy Policy 30 (2):125-129.

GIDB. 2003. GIDB Profile. Gujarat Infrastructure Development Board 2003 [cited January 2003]. Available from http://www.gidb.org/intd.htm.

GoG. 2003. Gujarat Electricity Industry (Reorganisation and Regulation) Act 2003. GERC 2003 [cited July 20 2003]. Available from http://www.gercin.org/DEFAULT.HTM.

GoGa. 2003. Socio-economic Review Gujarat State, 2002-03. Gandhinagar: Government of Gujarat, Directorate of Economics and Statistics.

Gunaratne, L. 2002. Rural Energy Services: Best Practices. New Delhi: USAID.

Harriss-White, B., and G. White. 1996. Corruption Liberalisation and Democracy. IDS Bulletin 27 (2):1-6.

ICRAa. 2003. Gujarat Power Sector. New Delhi: Power Finance Corporation.

ICRAb. 2003. Rating of State Power Sectors. New Delhi: ICRA Limited.

IEA, and OECD. 2002. Electricity in India : providing power for the millions. Paris: International Energy Agency : OECD.

Janakarajan, S. 2003. Irrigation: The Development of an Agro-Ecological Crisis. In Rural India Facing the 21st Century, edited by S. Janakarajan. London: Anthem.

Jenkins, R. 1999. Democratic Politics and Economic Reform in India. Cambridge: Cambridge University Press. 
Jongh, Jan de, and Remi Rijs. 2000. Newsletter on Small Scale Wind Energy Systems. Arrakis, December 2000 [cited January 29 2003]. Available from http://www.arrakis.nl/sswes_dec_2000_def.htm.

Joshi, Rajendra. 2003. Managing Director, SAATH. Ahmedabad, January 5. Personal Interview

Kannan, K.P., and N. V. Pillai. 2000. Plight of the Power Sector in India: SEBs and their Saga of Inefficiency. Thiruvananthapuram: Centre for Development Studies.

Karlson, F. 2002. Rural Energy Services Legal and Regulatory Review. New Delhi: USAID.

Khan, M.H., and K.S. Jomo. 2000. Introduction. In Rents, Rent-Seeking and Economic Development, edited by K. S. Jomo. Cambridge: Cambridge University Press.

Kuber, Girish. 2003. Western states face power shortage. Economic Times of India, April 11.

MoF. 2003. Economic Survey 2002-03. New Delhi: Ministry of Finance and Company Affairs, Government of India.

MoP. 2002. Distributed Generation Report. New Delhi: Ministry of Power.

MoP. 2003. Power Sector Profile, Western Region. Ministry of Power 2003 [cited July 24 2003]. Available from http://powermin.nic.in/power-profileWR_files/v3_document.htm.

Morris a, Sebastian. 2002 . The Challenge to Governance in India. In India Infrastructure Report 2002, edited by S. Morris. New Delhi: Oxford University Press.

Morris c, S. 2002. Professor, Indian Institute of Management. Ahmedabad, December 20. Personal Interview

Morris, Sebastian. 1999. GEB Reforms: A Note on Regulatory Strategy and an Approach to Privitisation. IIM-Ahmedabad Working Paper 99 (11-04):41.

Morris, Sebastian. 2000. Restructuring GEB: Outline of a Strategy and Proposal for Action. IIM Ahmedabad Working Paper 2000 (03-12):21.

NCAER. 2002. West and Central India Human Development Report. Edited by N. C. o. A. E. Research. Delhi: Oxford University Press.

Neudoerffer, Cynthia, Preeti Malhotra, and P. Venkata Ramana. 2001. Participatory rural energy planning in India -- a policy context. Energy Policy 29 (5):371-381.

Padmanaban, S. 2003. Electricity Act: Winners and Losers. Winrock 2003 [cited August 10 2003]. Available from http://www.renewingindia.org/news1 july3 head.html.

Padmanaban, S., and Ashok Sarkar. 2001. Electricity Demand Side Management (DSM) in India: A Strategic and Policy Perspective. Paper read at International Conference on Distribution Reforms, October 12, at New Delhi.

Palmer-Jones, R. 1994. Groundwater Markets in South Asia: A Discussion of Theory and Evidence. In Selling Water: Conceptual and Policy Debates Over Groundwater Markets in India, edited by M. Moench. San Francisco: Natural Heritage Institute.

Pandu, H. 2003. Assessing the Impact of Power Sector Reforms in Orissa. In Working Paper Series. Anand, Gujarat: Institute of Rural Management.

Parikh, Jyoti, and Kirit Parikh. 2002. Reforms in the Power Sector. In India Development Report 2002, edited by R. Radhakrishna. New Delhi: Oxford University Press.

Patel, K.B. 2003. Chief Engineer for Distribution, GEB. Vadodara, January.

Patil, S.B. 2003. Assistant Director, Gujarat Energy Development Agency. Vadodara, January.

PC. 2002. Annual Report (2001-02) on The Working of State Electricity Boards \& Electricity Departments. New Delhi: Planning Commission, GoI.

PLR. 1998. The Captive Report. New Delhi: Power Line Research.

Prakash. 2003. Re-imagination of the State and Gujarat's Electoral Verdict. Economic and Political Weekly 38 (16):1601-1610. 
PTI. 2003. Gujarat govt announces steps to overcome GEB deficit. Economic Times of India, March 12.

Raghu, Sunil. 2003. Revise PPAs, Gujarat tells IPPs. Economic Times of India, August 25.

Ramanathan, K. 2002. Regulatory Issues in Promotion of Renewables. Regulateri (12):6-7.

Rao, M.G., K.P. Kalirajan, and R. Shand. 1998. The Economics of Electricity Supply in India. Delhi: Macmillian India.

Rao, S. L. 2002. The Political Economy of Power. Economic and Political Weekly.

Rao, S. L. 2003. Electricity Bill 2001, Many Shortcomings, but a Step Forward. Economic and Political Weekly 28 (5).

Ravindranath, N.H., and D.O. Hall. 1995. Biomass, Energy, and Environment: A Developing Country Perspective from India. Oxford: Oxford University Press.

Shah a, Rakesh. 2003. Deputy Director, Gujarat Electricity Regulatory Commission. Ahmedabad, February 3. Interview

Shah, Sanjay. 1999. Techno-economic Feasibility Study of Liquid Based Small/Medium Power Project in Gujarat. MS-100, School of Management Studies, Indira Gandhi National Open University, New Delhi.

Sharma, R.K. 2003. Member (Technical), Gujarat Electricity Regulatory Commission. Ahmedabad, January 4. Personal Interview

Singh, H., D. Mishra, and N. M. Nahar. 2002. Energy use pattern in production agriculture of a typical village in arid zone, India--part I. Energy Conversion and Management 43 (16):2275-2286.

Smith, Nigel. 1998. Low-cost electrification : affordable electricity installation for lowincome households in developing countries, Intermediate Technology working papers. London: Intermediate Technology Publications.

Srivastava, Rajendra. 2002. Reforms Move Faster. Indian Infrastructure, August, 36-39.

Srivastava, Shri MM. 2003. Interview, Gujarat Electricity Board, Member (Finance). Gandhinagar, 7 January.

TERI. 2003. Third Party Sales - Concepts, issues and recommendations for Gujarat. GERC 2003 [cited April 2 2003]. Available from http://www.gercin.org.

Thillai, R. A. 2000. Power sector reform in Orissa: an ex-post analysis of the causal factors. Energy Policy 28 (10):657-669.

Thillai, Rajan A. 2003. Principal players in utility restructuring: the case of Orissa. Energy Policy 31 (5):431-441.

Thukur, T.N. 2002. Developments in the India Power Sector: Vision for the Future. Regulateri (12):8-11.

TII. 2002. Corruption in India: an empirical study. New Delhi: Transparency International India \& ORG-MARG Research.

TNN. 2002. Power utilities told to end free supplies, cross-subsidies. Economic Times of India, October 1.

TNN. 2003. Modi scraps 25\% relief on domestic power bills. Economic Times of India, February 26.

USDoE. 2001. An Energy Overview of India. Washington, DC: United States Department of Energy. 